University of Nebraska - Lincoln

DigitalCommons@University of Nebraska - Lincoln

\title{
AERONET Remotely Sensed Measurements and Retrievals of Biomass Burning Aerosol Optical Properties During the 2015 Indonesian Burning Season
}

\author{
T. F. Eck \\ B. N. Holben \\ D. M. Giles \\ I. Slutsker
}

A. Sinyuk

See next page for additional authors

Follow this and additional works at: https://digitalcommons.unl.edu/usnavyresearch

This Article is brought to you for free and open access by the U.S. Department of Defense at

DigitalCommons@University of Nebraska - Lincoln. It has been accepted for inclusion in U.S. Navy Research by an authorized administrator of DigitalCommons@University of Nebraska - Lincoln. 


\section{Authors}

T. F. Eck, B. N. Holben, D. M. Giles, I. Slutsker, A. Sinyuk, J. S. Schafer, A. Smirnov, M. Sorokin, J. S. Reid, A. M. Sayer, N. C. Hsu, Y. R. Shi, R. C. Levy, A. Lyapustin, Muhammad Arif Rahman, Soo-Chin Liew, Santo V. Salinas Cortijo, Tan Li, Daniel Kalbermatter, Kwoh Leong Keong, Muhammad Elifant Yuggotomo, Fanni Aditya, Maznorizan Mohamad, Mastura Mahmud, Tan Kok Chong, Hwee-San Lim, Yeap Eng Choon, Gumilang Deranadyan, Sheila D. A. Kusumaningtyas, and Edvin Aldrian 


\section{JGR Atmospheres}

\author{
RESEARCH ARTICLE \\ 10.1029/2018JD030182 \\ Key Points: \\ - AERONET Version 3 screening \\ allows many more AOD especially at \\ longer wavelengths than Version 2 \\ for very high smoke AOD conditions \\ - Retrieved very high aerosol single \\ scattering albedo and large \\ fine-mode particle size are \\ consistent with aerosol dominated \\ by peatland burning \\ - MODIS satellite retrieval algorithms \\ of AOD (collection 6.1) screened out \\ a significant number of high \\ fine-mode AOD days during the \\ event
}

Correspondence to:

T. F. Eck,

thomas.f.eck@nasa.gov

Citation:

Eck, T. F., Holben, B. N., Giles, D. M., Slutsker, I., Sinyuk, A., Schafer, J. S., et al. (2019). AERONET remotely sensed measurements and retrievals of biomass burning aerosol optical properties during the 2015 Indonesian burning season. Journal of Geophysical Research: Atmospheres, 124, 4722-4740. https://doi.org/10.1029/2018JD030182

Received 6 DEC 2018 Accepted 19 MAR 2019

Accepted article online 1 APR 2019

Published online 26 APR 2019

(c)2019. American Geophysical Union. All Rights Reserved.

\section{AERONET Remotely Sensed Measurements and Retrievals of Biomass Burning Aerosol Optical Properties During the 2015 Indonesian Burning Season}

\author{
T. F. Eck ${ }^{1,2}$ (D, B. N. Holben ${ }^{1}$, D. M. Giles ${ }^{1,3}$ D, I. Slutsker ${ }^{1,3}$, A. Sinyuk ${ }^{1,3}$, J. S. Schafer ${ }^{1,3}$,
}

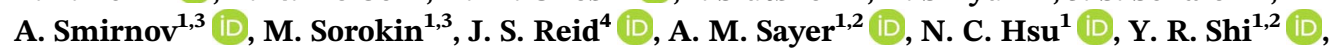
R. C. Levy' (D), A. Lyapustin' (iD, Muhammad Arif Rahman', Soo-Chin Liew6 (iD, Santo V. Salinas Cortijo ${ }^{6}$ (D), Tan $\mathrm{Li}^{6}$, Daniel Kalbermatter ${ }^{6}$ (D), Kwoh Leong Keong ${ }^{6}$,

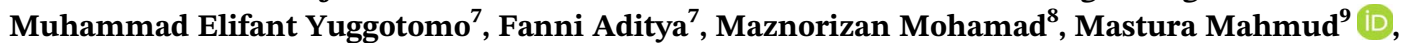
Tan Kok Chong ${ }^{10}$, Hwee-San Lim ${ }^{11}$ (D), Yeap Eng Choon ${ }^{11}$, Gumilang Deranadyan ${ }^{12}$, Sheila D. A. Kusumaningtyas ${ }^{13}$ iD, and Edvin Aldrian ${ }^{14}$

${ }^{1}$ NASA Goddard Space Flight Center, Greenbelt, MD, USA, ${ }^{2}$ Universities Space Research Association, Columbia, MD, USA, ${ }^{3}$ Science Systems and Applications Inc., Lanham, MD, USA, ${ }^{4}$ Naval Research Lab, Monterey, CA, USA, ${ }^{5}$ Agency for Meteorology Climatology and Geophysics, Jakarta, Indonesia, ${ }^{6}$ Centre for Remote Imaging, Sensing and Processing, National University of Singapore, Singapore, ${ }^{7}$ BMKG Staklim Mempawah, Pontianak, Indonesia, ${ }^{8}$ Malaysian

Meteorological Department, Petaling Jaya, Malaysia, ${ }^{9}$ Social Sciences and Humanities, Universiti Kebangsaan Malaysia, Bangi, Malaysia, ${ }^{10}$ Stesen Meteorologi Kuching, Kuching, Malaysia, ${ }^{11}$ School of Physics, Universiti Sains Malaysia, Penang, Malaysia, ${ }^{12} \mathrm{BMKG}$, Jambi, Indonesia, ${ }^{13}$ The Indonesia Agency for Meteorology Climatology and Geophysics, Jakarta, Indonesia, ${ }^{14}$ Agency for Assessment and Application of Technology, Jakarta, Indonesia

Abstract An extreme biomass burning event occurred in Indonesia from September through October 2015 due to severe drought conditions, partially caused by a major El Niño event, thereby allowing for significant burning of peatland that had been previously drained. This event had the highest sustained aerosol optical depths (AODs) ever monitored by the global Aerosol Robotic Network (AERONET). The newly developed AERONET Version 3 algorithms retain high AOD at the longer wavelengths when associated with high Ångström exponents (AEs), which thereby allowed for measurements of AOD at $675 \mathrm{~nm}$ as high as approximately 7, the upper limit of Sun photometry. Measured AEs at the highest monitored AOD levels were subsequently utilized to estimate instantaneous values of AOD at $550 \mathrm{~nm}$ in the range of 11 to 13, well beyond the upper measurement limit. Additionally, retrievals of complex refractive indices, size distributions, and single scattering albedos (SSAs) were obtained at much higher AOD levels than possible from almucantar scans due to the ability to perform retrievals at smaller solar zenith angles with new hybrid sky radiance scans. For retrievals made at the highest AOD levels the fine-mode volume median radii were $\sim 0.25-0.30$ micron, which are very large particles for biomass burning. Very high SSA values ( $\sim 0.975$ from 440 to $1,020 \mathrm{~nm}$ ) are consistent with the domination by smoldering combustion of peat burning. Estimates of the percentage peat contribution to total biomass burning aerosol based on retrieved SSA and laboratory measured peat SSA were $\sim 80-85 \%$, in excellent agreement with independent estimates.

\section{Introduction}

Episodic and extensive biomass burning in Southeast Asia in recent decades has led to severe local and even significant global effects (e.g., see review in Reid et al., 2013). Especially during drought years when drained peatlands burn (e.g., Field et al., 2009; Heil et al., 2007; Kaiser et al., 2016; Kusumaningtyas, Aldrian Arif Rahman, et al., 2016; Nichol, 1998) the very high concentrations of atmospheric particles has led to significant health effects including possibly several thousand excess mortalities (Crippa et al., 2016). Due to the vast amounts of carbon stored in organic peat soils, partial burning of these peat layers in dry years releases very large amounts of carbon into the atmosphere. Huijnen et al. (2016) estimated that the emission of carbon dioxide $\left(\mathrm{CO}_{2}\right)$ from biomass burning in this region during September-October 2015 exceeded the daily emission rate from fossil fuel combustion in the entire European Union. During the even more extensive drought and biomass burning event that occurred in 1997-1998 in the same region, Page et al. 
(2002) estimated that the emissions of carbon into the atmosphere from this largely peat dominated burning was equivalent to $13 \%$ to $40 \%$ of the global mean fossil fuel emissions of total carbon.

As a result of a very strong El Niño event occurring in 2015 coupled with a positive phase Indian Ocean Dipole (Pan et al., 2018), associated major shifts in atmospheric circulation caused a severe drought to develop throughout Indonesia and the Maritime Continent. This 2015 El Niño triggered drought in Indonesia was second only to that of 1997-1998 (in recent decades; Field et al., 2016), which occurred during an even stronger El Niño event. As a result of these strong droughts, the biomass burning associated with agricultural practices was able to spread farther than in typical rainfall years, plus peat fuels were able to burn more effectively due to deeper drying of these soils. Draining and drying of peatlands for the purpose of expanding agriculture especially palm oil plantations (Miettinen, Hooijer, et al., 2017; Page \& Hooijer, 2016; Sumarga et al., 2016) created additional conditions conducive to the burning of the underground organic peat soils that occurred primarily in historically susceptible southern Borneo (Kalimantan) and southeastern Sumatra. Once such peat fires are initiated, they typically burn until monsoonal inundation —-sometimes months later (Reid et al., 2013). Huijnen et al. (2016) utilized satellite data observations of fire radiative power and carbon monoxide $(\mathrm{CO})$, in situ measured smoke data plus data assimilation and modeling to estimate the extent of the emissions from the 2015 biomass burning event in September through October in Indonesia. This event produced carbon emissions that exceeded every year since the major El Niño event induced severe drought in 1997-1998. They mapped the major peat burning areas in southeastern Sumatra and southern Borneo showing that the highest carbon dioxide emissions occurred in regions with peat soils and estimated that the peat deposits burned to an average depth of $26 \mathrm{~cm}$.

Regarding regional pollution impacts, Aouizerats et al. (2015) modeled the transport of smoke from Indonesian biomass burning regions in other years to Singapore, an urban center that is at times severely impacted by particulate pollution from these smoke events. Additionally, Kusumaningtyas and Aldrian (2016) analyzed back trajectory analyses, satellite-determined hot spots, and aerosol properties from AERONET and satellite to investigate transboundary transport of smoke in 2013 from Sumatera, Indonesia, to Singapore during regional air pollution events.

Analysis and simulations by Fernandes et al. (2017) suggest that continued warming trends in Indonesia are likely to lead to increased fire frequency in the region even without El Niño events, as a result of drying from increased evapotranspiration and reduced soil moisture content. Additionally, Taufik et al. (2017) report that Borneo has experienced a hydrological drying trend for more than 100 years thereby resulting in additional tree mortality and further enhancing fire susceptibility during droughts associated with El Niño events. Therefore, even though there is large uncertainty in amplitude and frequency of future El Niño events implied by modeling (Ham \& Kug, 2016), there may be a greater tendency for fire frequency in Indonesia in the future from potentially higher temperatures and greater hydrological drying.

While seasonal biomass burning is a common feature to the region, ultimately, the meteorology and burning behavior in 2015 resulted in the strongest societal impact on record since the 1997-1998 event. The World Bank estimates that the 2015 fires in Indonesia cost at least \$16.1 billion U.S. dollars (Glauber et al., 2015), which is more than double the cost of reconstruction incurred from the 2004 tsunami in Indonesia (Aceh province). The short-term effects on human health from respiration of the particles in the haze was included but not the long-term health effects that may be even greater. Also included were costs for agriculture, school closures, tourism, trade, transportation, and forestry.

As discussed in Reid et al. (2013), it is the most significant biomass burning events in Southeast Asia that are the hardest to characterize. Near saturation of top of atmosphere radiance signals coupled with high cloud cover fractions pose daunting satellite remote sensing retrieval environments. Satellite hot spot products have difficulty capturing the low-temperature peat burning fires. Even past versions of direct AERONET aerosol optical depth (AOD) processing schemes had significant difficulty in full characterization of these events.

In this paper, we primarily analyze AERONET measurements of spectral AOD plus retrievals of size distributions and single scattering albedo (SSA) to characterize the optical properties of the biomass burning aerosols that were emitted during this 2015 event in Indonesia. In particular, new AERONET Version 3 data products were utilized to better understand this event as these provide the capability to investigate more fully the higher AOD episodes that previous Version 2 data screening eliminated. Additionally, a 
new version of the Cimel Sun-sky radiometer with advanced capability was deployed in two sites impacted by this event: Palangkaraya, Indonesia, (southern Borneo) in one of the major biomass burning source regions and also Singapore, a downwind site $\sim 1,200 \mathrm{~km}$ from southern Borneo and $\sim 500 \mathrm{~km}$ from southern Sumatra that was heavily impacted by these biomass burning emissions from Indonesia in 2015. We also present some of the standard Moderate Resolution Imaging Spectroradiometer (MODIS) satellite remote sensing retrievals of midvisible AOD during this event, noting that this topic, including recently developed algorithms to measure higher AOD events, are much more thoroughly investigated in other work (Shi et al., 2019).

\section{Instrumentation, Data, and Methodology}

Over the past decade, AERONET enhanced its deployment of Sun photometers in the Maritime Continent as part of the seven Southeast Asian Studies program (Reid et al., 2013; Lin et al., 2013). During the major biomass burning episode in Southeast Asia in 2015 there were six AERONET sites operating during the peak burning months of September through October. These site deployments included existing AERONET long-term monitoring sites in both Singapore and Indonesia. However, the analysis presented here focuses primarily on two sites that had the new Cimel Model-T instruments with advanced capabilities, at locations in Singapore and Palangkaraya, Indonesia.

\subsubsection{AERONET Instrumentation}

AERONET utilizes the CIMEL Electronique CE-318 Sun-sky radiometer for its AOD and Sun-sky measurements in its global network. Holben et al. (1998) provides a description of instruments and their use in detail. However, a brief description is provided here. The CE-318 automatically tracks the Sun to provide AOD and sky radiance for retrievals with a $1.2^{\circ}$ full field of view (FOV). There are a number of minor instrument variations between sites, but in this study, the more standard instrument configuration was used with AOD measurements at eight wavelengths $(340,380,440,500,675,870,1,020$, and 1,640), plus 940-nm water vapor. Sampling rates varied by site, with some sites attempting an AOD measurement every 15 min, while most made measurements approximately every $3 \mathrm{~min}$ to obtain high temporal resolution data. It takes $\sim 8 \mathrm{~s}$ to scan all wavelengths utilizing a motor-driven filter wheel to position each filter in front of the detector, repeated three times within a minute, to provide an ensemble mean and information for cloud screening as described below. Ion-assisted deposition interference filters were used with full width at half maximum band pass of $10 \mathrm{~nm}$, except for the 340- and 380-nm channels at 2-nm band pass. The estimated uncertainty in AERONET measured AOD, due primarily to calibration uncertainty, is 0.01-0.02 at optical air mass of one for network field instruments (with the highest errors in the ultraviolet [UV]; Eck et al., 1999). This estimate is consistent with Schmid et al. (1999) who compared AOD values derived from four different solar radiometers (including an AERONET Sun-sky radiometer) operating simultaneously together in field conditions and found that the AOD values from 380 to $1,020 \mathrm{~nm}$ agreed to within 0.015 (root-mean-square). More recently, Barreto et al. (2016) found similar results with the latest version of the Cimel. The sky radiances are calibrated versus frequently characterized integrating spheres at the National Aeronautics and Space Administration (NASA) Goddard Space Flight Center to an absolute accuracy of 5\% or better (Holben et al., 1998).

All analyses utilized Level 2 data from the new Version 3 spectral AOD product outlined by Giles et al. (2019). Most notably Version 3 updated its cloud screening algorithm, which in part continues to rely on the higher temporal frequencies of cloud optical depth versus AOD, especially optical depth triplet variability within a 1-min scanning cycle. This triplet variability is defined as the maximum minus minimum AOD of the three values taken in a 1-min time interval for each wavelength, with all spectral channels in Version 2 being checked for triplet range. In the new Version 3 cloud screening algorithm, only the 675-, 870-, and 1,020-nm channels are checked where the triplet range for all three wavelengths must be within 0.01 or $0.015 *$ AOD (whichever is greater). Since fine-mode AOD decreases rapidly with increasing wavelength, while coarse-mode AOD and/or cloud droplet optical depth is more spectrally flat, the triplet variance at longer wavelengths is more attributable to supermicron radius particle/droplet variation (dust or cloud). A secondary cloud screening check is made using the 440- to 870-nm AE; if the value exceeds 1.0 for an instantaneous measurement then even small numbers of AOD observations per day are retained in Level 2. Previously, three cloud-screened observations per day were required in Version 2 Level 2 database. Finally, there is a cloud screening check in Version 3 for cirrus that does not utilize temporal variance for 
cloud detection but rather relies on the sky radiances within $6^{\circ}$ scattering angle of the Sun. If the angular slope in scattering angle of the measured sky radiances in the solar aureole is sufficiently steep then there likely are cirrus cloud crystals present (due to very strong forward scattering) and there is a threshold on this angular dependence for determining cirrus presence (Giles et al., 2019). This check is particularly important for the current study as Southeast Asian data have been shown to suffer from cirrus contamination (Chew et al., 2011).

The maximum AOD that can be measured by AERONET (and all Sun photometer types) is AOD $* m<7$ where $m$ is the optical air mass or approximately the secant of the zenith angle for angles $<70^{\circ}$. At these values the Sun is no longer visible (the direct beam signal is nearly completely attenuated with $0.1 \%$ spectral direct beam transmission) and significant diffuse radiation is present (Sinyuk et al., 2012). Thus, for Sun at perfect zenith AODs as high as 7 can be measured, whereas for $60^{\circ}$ (or an optical air mass of 2), the maximum measurable AOD is $~ 3.5$. Importantly for this study in particular, in Version 3 very high AOD data (when AOD $[870 \mathrm{~nm}]>0.5$ ) are retained in the longer visible to near-infrared wavelengths (675 to $1,640 \mathrm{~nm}$ ) if the $\mathrm{AE}$ is sufficiently high ( $>1.2$ for 675 to $1,020 \mathrm{~nm}$ or $>1.3$ for 870 to $1,020 \mathrm{~nm}$ ) even when the UV and visible wavelengths direct beam signal are completely attenuated. This is possible since the AOD is lower in the near-infrared wavelengths than in the UV and visible, and since the four-quadrant detector that optimizes the solar tracking in the Cimel instrument is only sensitive to the near-infrared wavelengths (while the UV and visible wavelengths are blocked). Therefore, the instrument can track the Sun precisely even when the visible direct beam irradiance is nearly completely attenuated. The complete set of Version 3 cloud screening and quality assurance (QA) algorithms are provided in Giles et al. (2019).

\subsubsection{AERONET Inversion Methodology}

The almucantar sky radiance scans made by the CIMEL instruments are performed at fixed elevation angles equal to the solar elevation with $\pm 180^{\circ}$ azimuthal sweeps made sequentially at four wavelengths (440, 675 , 870 , and $1,020 \mathrm{~nm}$ ). These are made in both the morning hours and afternoon hours at optical air masses of $4,3,2$, and $1.7\left(75^{\circ}, 70^{\circ}, 60^{\circ}\right.$, and $54^{\circ}$ solar zenith angle [SZA], respectively) plus once per hour in between. AERONET retrievals are also made utilizing hybrid sky scans with the new Cimel instruments version Model-T. The sky scan made with the hybrid methodology simultaneously moves in both the azimuthal and zenith angle directions, thus performing a scan that is in general intermediate between the almucantar and principal plane (varies the zenith angle while maintaining a fixed azimuth).

Hybrid and almucantar directional scan radiance data are combined with measured AOD data at identical wavelengths to retrieve optically equivalent column-integrated volume size distributions and aerosol refractive indices utilizing the algorithms as developed by Dubovik and King (2000) and Dubovik et al. (2006). These retrieved aerosol properties are utilized to derive additional parameters such as asymmetry parameter, SSA, and phase function. Only the new Version 3 Level 2 retrievals with the quality controls described in Holben et al. (2006) are presented in this study. The percentage particles of spheroidal and spherical shape required to give the best fit to the measured angular distribution of spectral sky radiances is also determined by the AERONET retrieval algorithm. Dubovik et al. (2006) provides further details on these retrieval algorithms.

In this study, only almucantar scans taken at SZAs greater than $\sim 50^{\circ}$ are analyzed and presented in order to ensure sky radiance measurements over a sufficiently wide range of scattering angles. The scattering angle range of measured sky radiances for an almucantar scan performed at $50^{\circ} \mathrm{SZA}$ is $100^{\circ}$, while at $75^{\circ}, \mathrm{SZA}$ it is $150^{\circ}$. However, the newly developed hybrid scans available only with the recent Model-T Cimels can provide directional sky radiance measurements with $100^{\circ}$ scattering angle range at a SZA of only $25^{\circ}$. This is a major advantage when AOD is extremely high as is the case studied here since the 440-nm AOD is required for the retrieval, and this wavelength will be nearly completely attenuated when SZA is large and AOD is high. Additional cloud screening for hybrid and almucantar sky radiance measurements (first, the AOD must pass the Level 2 quality control and cloud screening) is preformed through the requirement of symmetrical sky radiances on both sides of the Sun at equal scattering angles. These radiances from both sides of the scan that meet the symmetry threshold are then averaged before being used as input to the AERONET retrieval. Directional sky radiance measurements that are asymmetrical at a given scattering angle (due to inhomogeneous aerosol distributions or cloud on one side) are eliminated, and a retrieval only reaches Level 2 when the minimum number of measurements required in defined scattering angle ranges are met (see Holben 
et al., 2006). However, the hybrid criterion for the last scattering angle bin has a different minimum scattering angle limit $\left(\geq 75^{\circ}\right)$ than almucantars $\left(\geq 80^{\circ}\right)$ and a different minimum number of symmetric scattering angles $(N=2)$ than almucantars $(N=3)$, due to somewhat fewer scattering angle range measurements in the hybrid scan. Dubovik et al. (2000) found these AERONET inversions to be stable as determined by perturbation analyses accounting for random errors, instrumental data offsets and known uncertainties in the atmospheric radiation model.

Although few direct comparisons of size distributions between AERONET retrievals and in situ measurements have yet been published (none yet for Version 3), there are several specific regional aerosol types that have been compared. For example, for biomass burning aerosols Reid et al. (2005) compared regional mean volume median radii from source regions in southern Africa, South America, boreal zone, and temperate North America and found that AERONET retrievals versus in situ measurements of the diameter of finemode particles were often within $\sim 0.01 \mu \mathrm{m}$ of each other. In the Arabian Sea for fine-mode pollution particles observed during the INDOEX experiment, Clarke et al. (2002) showed volume size distribution lognormal fits from both aircraft and ship in situ measurements where the average accumulation mode volume peak radius values under high aerosol loading conditions ranged from 0.17 to $0.18 \mu \mathrm{m}$ with corresponding geometric standard deviations (widths) of 1.51 (for ship) and 1.43 (for aircraft). This compares very well to AERONET retrievals made at Kaashidhoo Island in the Maldives (in the INDOEX region), for observations when AOD $(440 \mathrm{~nm})>0.4$, of median radius of $0.18 \mu \mathrm{m}$ and width of 1.49 (1998-2000 multiyear average Version 2 values). For larger submicron-size aged Pinatubo volcanic stratospheric aerosols, Eck et al. (2010) discussed the relatively close agreement between in situ observations from stratospheric aircraft of 0.53- $\mu \mathrm{m}$ effective radius as reported by Pueschel et al. (1994) to AERONET retrievals made from observations in 1993 of $\sim 0.56-\mu \mathrm{m}$ peak volume radius. For coarse-mode particles (with supermicron radius), Reid et al. $(2006,2008)$ found excellent agreement between AERONET retrieved and in situ measured size for sea salt and desert dust aerosol, respectively. For aerosols of maritime origin, Smirnov et al. (2003) showed reasonable agreement between AERONET retrievals and in situ measurements of sea salt-dominated coarse-mode size distributions. Additionally, for coarse-mode dust size distributions in the Sahel region of West Africa Johnson and Osborne (2011) have shown good agreement between AERONET retrievals and in situ measurements from aircraft.

In this study, we followed the guidance from Dubovik et al. (2000) that only almucantar retrievals where 440-nm AOD is greater than 0.4 be used for analysis of spectral refractive indices and SSA. In fact, most retrievals analyzed in this paper had 440-nm AOD much higher than 0.4, often higher than 1. In southern Africa, for strongly absorbing fine-mode-dominated biomass burning aerosols, Leahy et al. (2007) found good agreement in 550-nm SSA, with differences between in situ measurements and AERONET retrievals of -0.01 . In the mid-Atlantic region of the United States for weakly absorbing anthropogenic fine-modedominated aerosol, Schafer et al. (2014) found excellent agreement between aircraft vertical profiled in situ measurements of SSA (550 nm) and AERONET-retrieved values (estimated at $550 \mathrm{~nm}$ from the mean of 440and 675-nm values), with an average difference of only $\sim 0.01$ for spatially and temporally matched observations. These offsets are significantly smaller than the nominal $\sim 0.03$ uncertainty of AERONET SSA in these circumstances. For the new Version 3 product at the extremely high AOD levels observed during the 2015 burning season in Indonesia (which often exceed 2 at $440 \mathrm{~nm}$ ) the estimates of SSA uncertainty for individual retrievals was $\sim 0.01$ (A. Sinyuk, personal communication, November, 15 2018).

\subsection{Satellite Aerosol Optical Depth Data Sets}

In this section, we describe multiple satellite products retrieved from MODIS satellite data, including the standard Collection 6.1 Dark Target (DT), Deep Blue (DB), and Multi-Angle Implementation of Atmospheric Correction (MAIAC) algorithms. Additionally, DB algorithm retrieval results from the Visible Infrared Imaging Radiometer Suite (VIIRS) satellite are also included.

\subsubsection{MODIS DT}

MODIS DT provides AOD at $550 \mathrm{~nm}$, with a nominal 10-km horizontal pixel size at nadir and $\sim 30-40 \mathrm{~km}$ at the swath edge. The upper retrieved limit of AOD for DT is $\sim 5$. The latest C6.1 MODIS DT algorithm used here is very similar to that from Collection 6 (C6, Levy et al., 2013); the main updates are related to sensor calibration, more conservative cloud screening, and the incorporation of a new surface reflectance model over urban surfaces (Gupta et al., 2016). Although most of the area discussed in this study is rural, this 
latter update may affect the comparison here because the AERONET site in Palangkaraya is located on the edge of the city.

\subsubsection{MODIS/VIIRS DB}

The C6.1 MODIS DB retrieval algorithm (Hsu et al., 2019) is a refinement of the previous C6. Like DT, DB provides AOD at $550 \mathrm{~nm}$ with a nominal 10-km nadir pixel size. The upper retrieval limit of AOD is 3.5, lower than DT. Changes made were largely to address sensor calibration degradation as well as known regional biases/artifacts identified (identified by Sayer et al., 2013), by improving QA tests and aerosol optical model assumptions.

Recently, the DB data product suite has been expanded to include AOD retrievals from the VIIRS (A. Sayer, personal communication, November 15, 2018), using a slightly updated version of the C6.1 DB algorithm. Due to sensor differences, this is at a slightly finer spatial resolution of 6-km horizontal pixel size at nadir; VIIRS also has a swath approximately 50\% wider than MODIS. Both of these factors lead to increased potential data coverage. One further refinement to the C6.1 algorithm important here for VIIRS is that the upper AOD limit is relaxed from 3.5 to 5 and an adjustment to cloud screening tests to improve detection of optically thick smoke. This update decreased the known sampling biases in spaceborne AOD data sets resulting from their omission. However, a side effect of this relaxation was that cloud contamination was found to increase. As a result, the QA flags for such pixels are set to low confidence. This reflects both the increased likelihood of cloud contamination in these data, as well as the fact that in extreme cases, limitations of the sensor and algorithmic assumptions mean that these retrievals are likely to be quantitatively less reliable than others.

\subsubsection{MAIAC}

The MAIAC algorithm employs time series analysis to improve accuracy of cloud and snow detection, aerosol retrievals, and atmospheric correction (Lyapustin et al., 2018). The MODIS Terra and Aqua C6 MAIAC aerosol product (MCD19A2), released in spring of 2018, was used in this work. MAIAC AOD is available globally over land at 1-km resolution on a Sinusoidal grid for cloud- and snow-free observations. The C6 MAIAC lookup tables limit maximal optical thickness to 4 at $0.47 \mu \mathrm{m}$, which is a clear limitation for massive biomass burning events including Indonesia fires of 2015; this upper limit is lower than that of DT but similar to DB.

\section{Results}

\subsection{Satellite-Detected Fire Counts and MODIS-Retrieved AOD}

Satellite monitoring of fire counts for 8-17 October 2015 (at the height of this biomass burning event) from MODIS satellite detection of hot spots utilizing the fire detection algorithm of Giglio et al. (2003) show a large number and density of fire counts in southern Kalimantan (Borneo Island) and in southeast Sumatra in Figure 1a. These same areas of high-density fire counts areas were identified by Huijnen et al. (2016) to be the major peatland regions with the corresponding greatest regional emissions of carbon dioxide in 2015. Note that they identified no peat soils on the southern part of the island of New Guinea, which also had a high number of fire counts and therefore estimated much lower carbon dioxide emissions from this region. Miettinen, Shi, et al. (2017) found that although peatlands covered only $12 \%$ of the study area (Sumatra, Peninsular Malaysia, and Borneo) 53\% of all MODIS measured hotspots occurred there during the 2015 burning season. They also determined that the fire density was very low in pristine peat swamp forests as compared to very high fire count density in deforested peatlands. Without doubt, these satellite fire detections are likely significantly understated as they are based on more limited polar orbiting measurements and peat fires tend to smolder at low temperatures that make them more difficult to monitor in the infrared wavelengths (Hyer et al., 2013).

Figure $1 \mathrm{~b}$ shows the MODIS RGB image (plus fire counts) of the same region (and for Borneo only in Figure 1c) as in Figure 1a for 1 day, for 10 September 2015, when AERONET-measured AOD at $675 \mathrm{~nm}$ at the Palangkaraya site was 6.91 at midday with an AE (675-1,640 nm) of 1.89 thereby indicating dominance by fine-mode aerosol. In this case, one can see that the majority of fire detections are on the smoke perimeter. In Figure 1d, MODIS satellite C6 DT algorithm retrievals of AOD for Borneo on this date show that retrievals were not made in the densest smoke areas, only on the edges or periphery where the AOD is much lower. This suggests that the operational C6 DT algorithm screened these heavy smoke features due to both cloud and a conservative filter that was intended to mask out conditions that are not optimal 

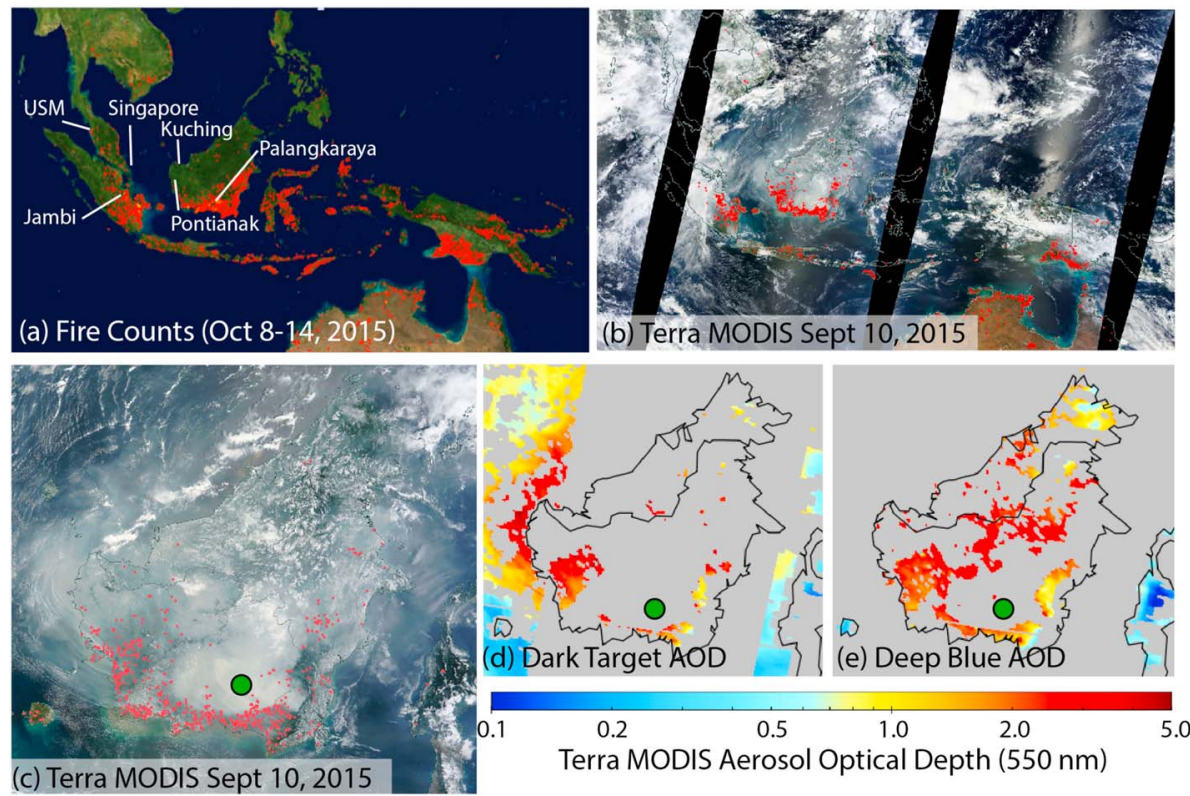

Terra MODIS Aerosol Optical Depth $(550 \mathrm{~nm})$

Figure 1. (a) MODIS Fire Counts for 8-17 October 2015 from National Aeronautics and Space Administration Rapid Response, fire detection algorithm developed by Giglio et al. (2003). (b) MODIS Terra image over the region for 10 September 2015 showing clouds, smoke, and fire counts, (c) zoomed in MODIS Terra image from 10 September 2015 over the island of Borneo, noting that on that day the Palangkaraya, Indonesia AERONET site had measured AOD (675 nm) at midday of 6.91 with an Ångström exponent $(675-1,640 \mathrm{~nm})=1.89$. (d) Retrievals of MODIS Dark Target AOD $(550 \mathrm{~nm})$ over Borneo on 10 September 2015 (e) AOD retrieved by the MODIS Deep Blue algorithm over Borneo on 10 September 2015. Note that the location of the Palangkaraya site is identified by a green circle in parts $\mathrm{c}, \mathrm{d}$, and e. AOD $=$ aerosol optical depth; MODIS = Moderate Resolution Imaging Spectroradiometer; USM = Universiti Sains Malaysia.

for retrieving aerosols (Shi et al., 2019). This type of event led to the development of a new high AOD event DT algorithm that relies in part on the aerosol optical properties that are retrieved from AERONET retrievals during the same event (Shi et al., 2019). Figure 1e is the same except for MODIS DB, indicating significantly greater coverage than the DT retrievals of AOD over the land areas in Borneo. However, neither the DT nor DB algorithms made AOD retrievals within $30 \mathrm{~km}$ of the Palangkaraya site on this day despite the aforementioned heavy smoke observed in the AERONET data.

Figure 2 shows the time series of AOD at $550 \mathrm{~nm}$ from the MODIS DT, DB algorithms (both C6.1), MAIAC C6, and VIIRS DB giving averages of all retrievals within 30-km radius of the AERONET site, as compared to Version 3 L2 AERONET measured daily averaged AOD for times when both 500- and 675-nm AOD data were available. The MODIS DT algorithm does not retrieve any AOD from 5 September through 12 October 2015 (>1 month) corresponding to the period with the consistently highest AOD as measured from AERONET. This is due to multiple reasons: (1) The extremely high aerosol loadings are mistaken as cloud by the low cloud mask, (2) these features are filtered out by inland-water mask as the retrieving conditions are not optimal, (3) the MODIS DT retrieved AOD are higher than the upper limit of AOD in the algorithm, which is caused by using a too absorbing aerosol model (Shi et al., 2019). Note that Shi et al. (2019) developed an event-based MODIS DT research algorithm targeting this fire event over Indonesia. This research product has increased data coverage and accuracy at high AOD range.

The DB and MAIAC algorithms have many more retrievals than DT during the high-AOD SeptemberOctober time period (13 and 15 days, respectively, compared to 5 for DT). These algorithms both have additional tests that are designed to offer better discrimination between thick smoke and clouds (Hsu et al., 2019; Lyapustin et al., 2018), resulting in this increased data coverage. The magnitudes are however limited by the aforementioned maxima of 3.5 for DB and 3.1 (at $550 \mathrm{~nm}$ ) for MAIAC.

The VIIRS DB algorithm provides retrievals on every day except the thickest few when the AERONET daily mean AOD at $550 \mathrm{~nm}$ was above 5. Although VIIRS does have a broader swath than MODIS, the primary reason for this extra coverage is the additional relaxation of cloud masking tests in cases of heavy smoke, 

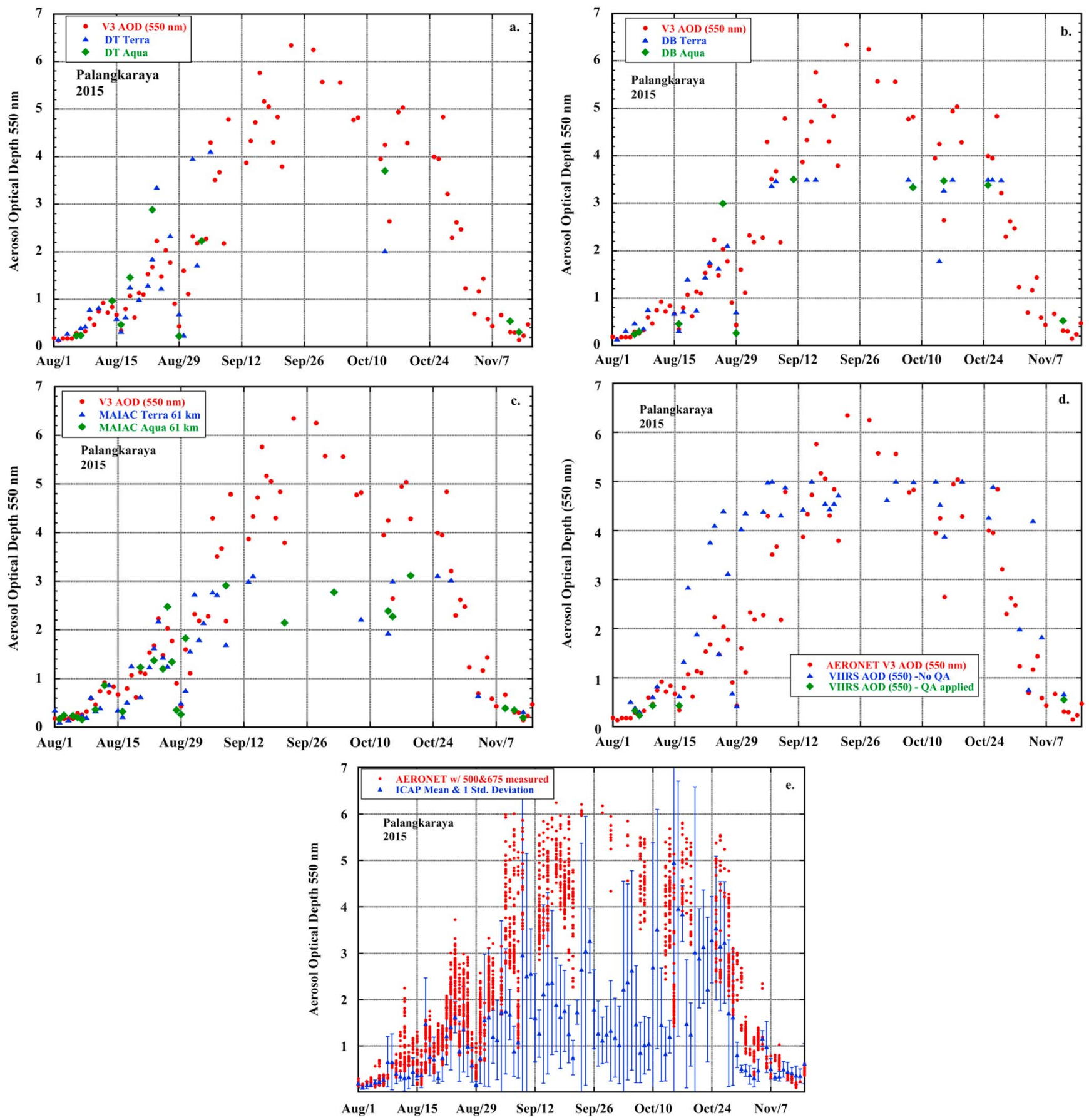

Figure 2. (a) Time series of 550-nm AOD at the Palangkaraya, Indonesia, site from 1 August through 15 November 2015. AERONET daily average data are V3 shown only when both 500- and 675-nm AOD were available. Also plotted are the Dark Target algorithm (C6.1) retrievals of AOD from both Terra and Aqua satellite overpasses. (b) Similar to (a) but with the Deep Blue algorithm (C6.1) retrievals of AOD from both Terra and Aqua satellite overpasses. (c) Similar to (a) but with the MAIAC algorithm (C6) retrievals of AOD from both Terra and Aqua satellite overpasses. (d) Similar to (a) but with the VIIRS algorithm retrievals of AOD afternoon satellite overpasses. (e) All instantaneous measurements of AERONET AOD $(550 \mathrm{~nm})$ plotted versus the multimodel ensemble mean and standard deviation from the four models in the ICAP 06 UTC hour forecasts at one degree latitude-longitude resolution. AOD = aerosol optical depth; DB = Deep Blue; $\mathrm{QA}=$ quality assurance; MAIAC = Multi-Angle Implementation of Atmospheric Correction; AERONET = Aerosol Robotic Network; VIIRS = Visible Infrared Imaging Radiometer Suite; ICAP = International Cooperative for Aerosol Prediction. 
designed to retain such events (Hsu et al., 2019). However, for this case, the whole of September-October is masked out by the QA flag, which is intentional as these extreme conditions are expected to be inherently more uncertain and more likely to suffer from cloud contamination. This is suggested by the comparison here, where VIIRS retrievals are somewhat higher than AERONET in late August, when AERONET AOD is still high (often around 2) but not yet at the levels at which the other algorithms fail. Outside of this peak period, the retrievals retained by QA filters match very well with AERONET and the other satellite data. This illustrates that in such extreme conditions, there is inherently a trade-off between coverage and uncertainty, and the right data set and filtering to choose is dependent on the precise scientific objectives of the analysis.

The International Cooperative for Aerosol Prediction (ICAP) multimodel ensemble mean 06 UTC hour forecasts (Sessions et al., 2015; P. Xian, personal communication, September, 15 2018) are also compared to the AERONET-measured AOD for dates when both 500- and 675-nm AODs were measured (Figure 2e). These four multispecies forecast models assimilate MODIS-retrieved C6 DT AOD and fire count data in addition to computing AOD from source functions in the models. The ICAP ensemble average AOD is much lower than the AERONET instantaneous measured values of AOD throughout most of the 2-month peak burning period of September through October. This is due in part to the lack of satellite retrievals on many of these days in addition to the undersampling of fire counts during the event, especially for the relatively lowtemperature smoldering combustion of peat soil.

\subsection{AERONET Measurements of AOD in Southeast Asia}

There were six AERONET sites established and operating in the region during this August-November 2015 biomass burning event. Three sites were located on the island of Borneo: Palangkaraya and Pontianak, both in Indonesia and Kuching, Malaysia. The other three sites were: Penang USM on the west coast of peninsular Malaysia, Singapore, and Jambi in southwestern Sumatra, Indonesia. Figures 3a and 3b show the 2015 biomass burning event time series of the Version 3 AOD at $870 \mathrm{~nm}$ for these six sites. The AOD levels increased steadily through August, remained very high during the peak burning periods of September through October, and then decreased rapidly in November as rains commenced putting an end to the burning and also removing aerosol by wet deposition. The highest measured AOD during this event occurred in the two sites located in major peat burning regions, Palangkaraya and Jambi. Unfortunately, equipment problems prevented the Jambi site from operating for 39 days, from 31 August through 8 October 2015, although this site had the highest AOD of the three sites not on Borneo when it began operating (with a replacement instrument) in October. Note that the highest 870-nm AOD measured out of all six sites occurred at Palangkaraya, with a maximum of 6.27 on both 5 and 19 October 2015. This value is lower than the Sun photometer measurement limit for overhead Sun of $\sim 7$. It is possible that the AOD at $870 \mathrm{~nm}$ did exceed the measurement limit on some days, at times other than near solar noon, possibly exceeding the AOD * $m<7$ limit. However, the data indicate that measurements in the near infrared wavelengths from 870 through 1,640 $\mathrm{nm}$ were made on most high AOD days during this event. Cloud screened and quality checked L2 AOD data at Palangkaraya occurred on 52 days of a maximum 61 days for all of September and October in 2015, suggesting a relatively complete characterization of the extremely high AOD during this event, since some of the missing days may possibly have had extensive cloud cover.

Multiyear time series of 870-nm AOD for the Palangkaraya and Singapore sites are shown in Figures 3c and 3d, respectively. There were only 4 years of Level 2 burning season data (August-November) available for Palangkaraya from 2012 through 2015. These years of Palangkaraya site data show a very wide range of smoke concentrations from biomass burning, however, ranging from relatively little in 2013 to very high levels during the extreme event in 2015. At the Singapore site there were 10 years of biomass burning season AOD data over the 2007 through 2016 time period. From the data at the Singapore site, it is obvious that 2015 had significantly exceeded all of the other years in the concentrations and duration of smoke transported from the burning regions to the site. However, note that in 2014 there were high AOD from significant biomass burning at the Palangkaraya site, while at Singapore the AOD did not increase proportionately, perhaps due to differences in atmospheric circulation between years. Additionally, the AOD levels at Singapore from biomass burning aerosols may result more from transport from the major source regions in Sumatra, which are significantly closer rather than the Palangkaraya region in Borneo.

The time series of cloud-screened near-infrared wavelength AOD (870, 1,020, and 1,640 nm) from both Version 2 (L2) and Version 3 (L2) at the Palagkaraya, Indonesia, site from 1 August through 15 

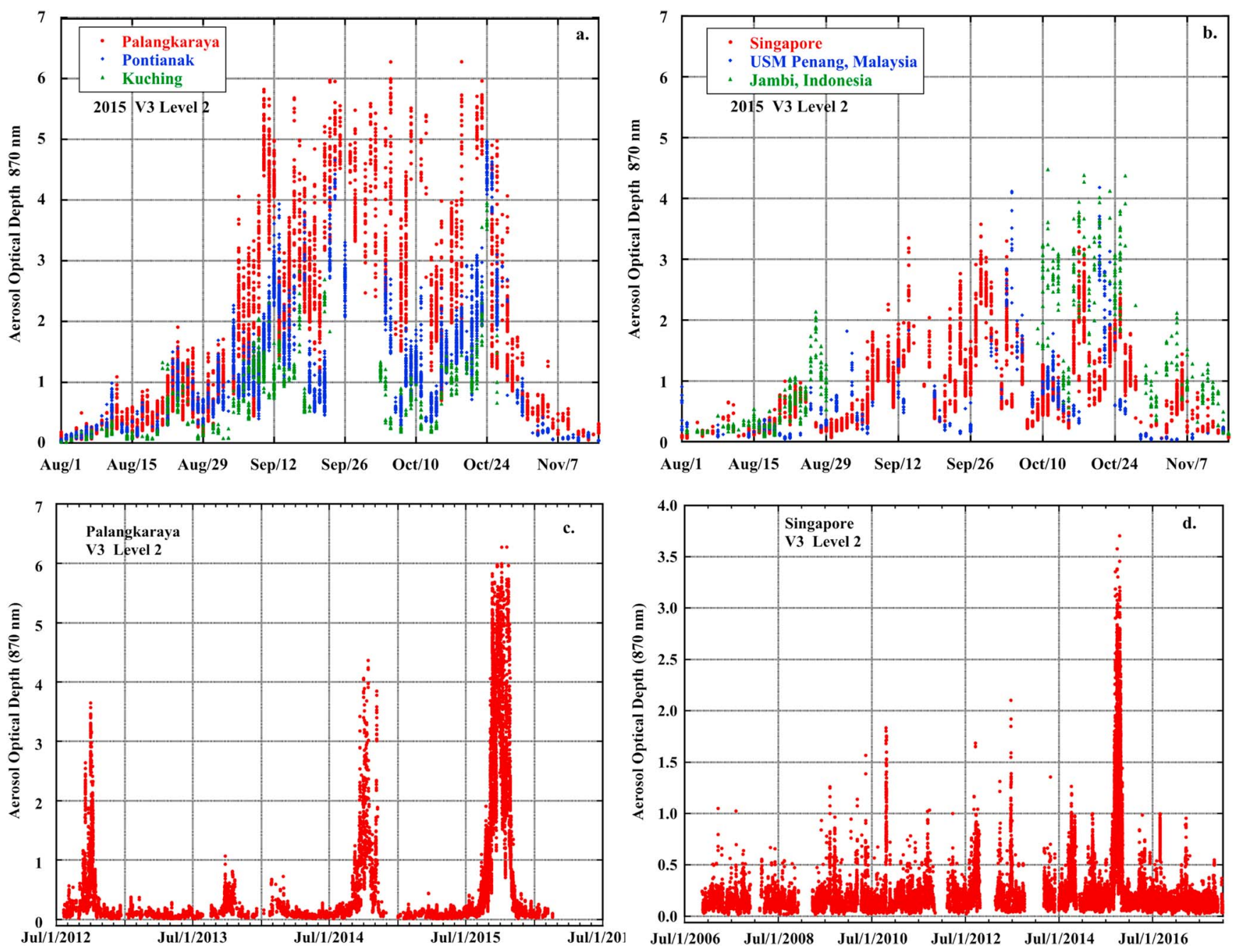

Figure 3. (a) Time series of the 870-nm AOD for the three Aerosol Robotic Network sites on Borneo island from 1 August through 15 November 2015. (b) Time series of the 870-nm AOD for two Aerosol Robotic Network sites on the Malayan Peninsula (USM Penang and Singapore) plus one on Sumatra island (Jambi) from 1 August through 15 November 2015 (c) Multiyear AOD $(870 \mathrm{~nm}$ ) time series of all Level 2 data from the Palangkaraya site from mid-2012 through early 2016. (d) Singapore site multiyear time series of L2 AOD $(870 \mathrm{~nm})$ from 2006 through 2017. AOD = aerosol optical depth; USM = Universiti Sains Malaysia.

November 2015 are shown in Figure 4. Significant differences exist in the way low signal data are processed in Versions 2 and 3. In Version 2, when the raw count signal decreases below 10 for the 440-nm channel, then all of the data for all channels in that spectral scan are eliminated to avoid significant bias in 440-nm AOD from diffuse radiation in the instrument FOV (Sinyuk et al., 2012). In Version 3, a low signal check is applied to all channels independently and channels with sufficiently high signal (to avoid significant biases from diffuse in FOV) are retained when $\mathrm{AE}$ is sufficiently high ( $>1.2$ for the 675 - to 1,020-nm range or $>1.3$ for $870-1,020 \mathrm{~nm}$; Giles et al., 2019). Therefore, AOD values in the longer wavelengths are retained since for fine-mode smoke the AOD deceases significantly as wavelength increases resulting in adequate signal for accurate AOD measurements in these wavelengths. A key aspect of the Cimel Sunsky radiometer is that the solar tracking four-quadrant detector has a blocking filter in front of it allowing only solar energy with wavelengths greater than $700 \mathrm{~nm}$ to reach the silicon detector, which is sensitive to a maximum wavelength of $\sim 1,050 \mathrm{~nm}$. Therefore, the detector utilized for solar tracking can accurately locate the Sun even when the fine-mode AOD is so high in the visible that the Sun cannot be seen with the human eye. Note that in Version 2 the highest cloud-screened AOD measured at $870 \mathrm{~nm}$ during this interval was only 3.2, while for Version 3, the highest AOD measured was about twice as high at $~ 6.3$. Additionally, there are many more measurements of AOD on many more days in Version 3 as compared 

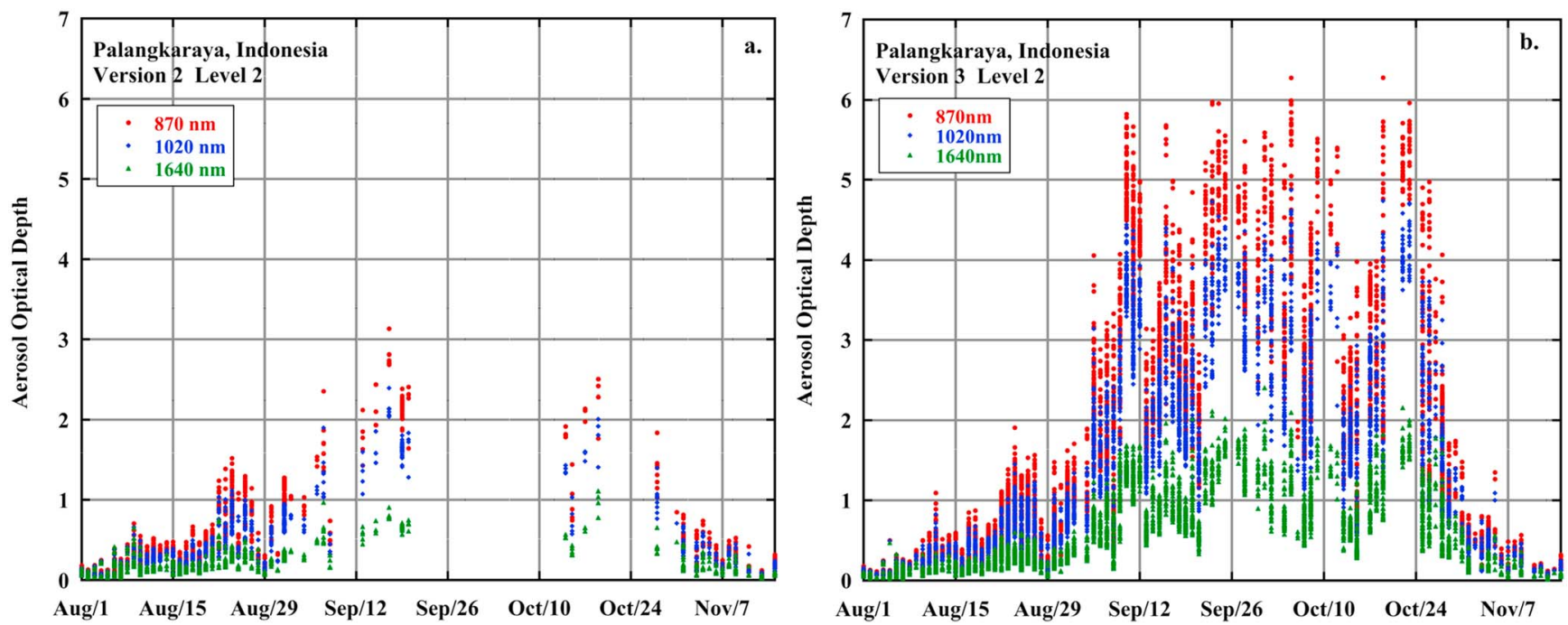

Figure 4. Time series of aerosol optical depth for the three longest measurement wavelengths $(870,1,020$, and 1,640 $\mathrm{nm})$ at the Palangkaraya, Indonesia, site from 1 August through 15 November 2015. Both graphs show Level 2 cloud-screened data, with the Version 2 data in (a) and the Version 3 data in (b).

to V2. For example, see especially the interval of days from 21 September through 12 October, plus other periods of very high AOD in Version 3, both before and after that time interval.

In Figure 5a, the time series of daily average AOD at $675 \mathrm{~nm}$ from 15 August through 15 November 2015 for the Palangkaraya AERONET site is shown. The maximum AOD value during this time interval is 7.1, which occurred at or near the maximum limit of Sun photometers to accurately measure AOD for overhead Sun (air mass $=1$ ). At AOD levels that exceed $\sim 7$ or AOD * air mass $>7$, the diffuse sky radiance in the instrument FOV $\left(1.2^{\circ}\right.$ for this Cimel) starts to become a significant fraction of the measured signal thereby biasing the calculation of AOD to lower values than the true value (Sinyuk et al., 2012). Note that there was no significant relationship between 675-nm AOD and total column water vapor amount (from AERONET retrievals) for this site and time interval, with linear regression explaining only $2 \%$ of the variance. Figure $5 \mathrm{~b}$ shows the extinction $\mathrm{AE}(\alpha ; 500-870 \mathrm{~nm})$ versus AOD at $550 \mathrm{~nm}$ for the same site and same dates as shown in Figure 5a. The 550-nm AOD was calculated from the $\alpha(500-870 \mathrm{~nm})$ values, this wavelength was selected since it is a typical reference wavelength for satellite retrievals of AOD. Note that for AOD exceeding 1 at $550 \mathrm{~nm}$, there was a general tendency of decreasing $\alpha$ as AOD increased. This is related to a general trend of increasing fine-mode particle size as AOD increases (see size distribution retrievals in section 3.4), likely related in part to secondary particle mass production and increased particle coagulation rates as aerosol concentrations increase (see Colarco et al., 2004; Reid \& Hobbs, 1998).

\subsection{Estimation of AOD When Sun Photometer Maximum Limit Is Exceeded}

It was not possible to measure the true AOD at $500 \mathrm{~nm}$ and even $675 \mathrm{~nm}$ on many days in September and October 2015 at Palangkaraya, since the biomass burning AOD was so high at times that the Sun photometer limit of $\sim 7$ was exceeded due to complete or nearly complete attenuation of the direct beam solar signal in those wavelengths. In order to estimate the AOD at $550 \mathrm{~nm}$ for all AERONET observation times when the Level 2 870-nm AOD was measured (maximum of $\sim 6$ was measured), a representative AE (500-870 nm) was utilized to estimate the AOD at $550 \mathrm{~nm}$. The AE (500-870 nm) computed from AOD measurements, shown in Figure 5b, ranged from $\sim 1.0$ to $\sim 1.4$ for the highest AOD levels. These limits were chosen as AE estimates for AOD $(550 \mathrm{~nm})$ levels exceeding 6 since there is a trend of AE decreasing as AOD increased. The retrievals of fine-mode radius also show a linear increase as AOD increases, through to the retrievals made at the highest AOD values (see section 3.4). Since there were no measured AE (550-870 nm) values for the very highest AOD days (when the 500-nm channel was not available), we assumed that there was a general continuation of the trend of decreasing $\mathrm{AE}$ as $\mathrm{AOD}$ increased, and this was factored into our selection of AE limits utilized for estimating 550-nm AOD. Utilizing these bounding AE values of 1.0 and 1.4, the instantaneous AOD values at $550 \mathrm{~nm}$ computed are shown in Figure 6. Maximum AOD at $550 \mathrm{~nm}$ as estimated in this way ranged from $\sim 11$ for assumed $A E=1.0$ and $\sim 13$ for assumed $A E=1.4$. These estimated 

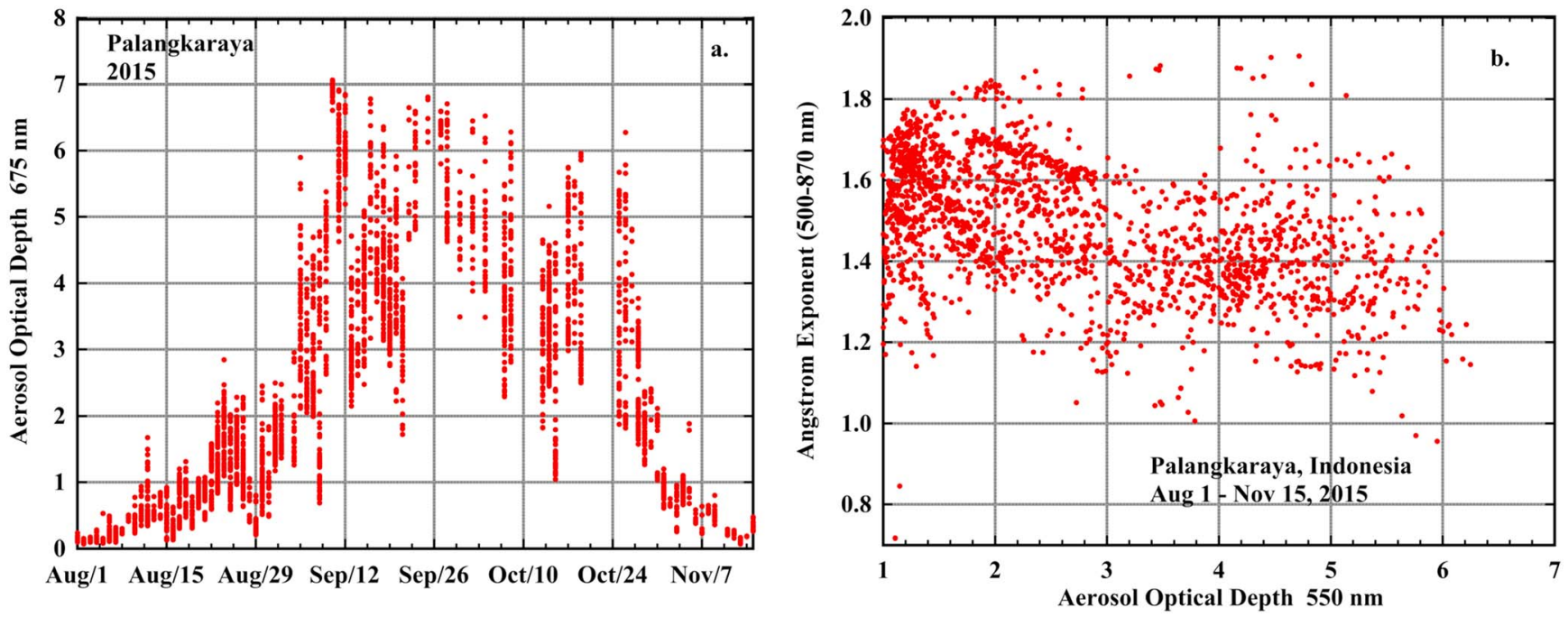

Figure 5. (a) Time series of aerosol optical depth at $675 \mathrm{~nm}$ at the Palangkaraya, Indonesia, site from 1 August through 15 November 2015. (b) Ångström exponent (500-870 nm) computed when V3 Level 2 500- and 870-nm aerosol optical depths were available.

AOD levels at midvisible exceed, to our knowledge, any values ever reported in the published literature. This biomass burning event in 2015 in Indonesia was the largest magnitude AOD event (occurring over an interval of months) in terms of AOD levels ever monitored by AERONET to date in the 25-year history of the network.

\subsection{Almucantar and Hybrid Scan Retrievals of Aerosol Size and Absorption}

Due to the very high AOD levels during this event, the almucantar retrievals of complex refractive index and size distribution were made on very few days. This was partly due to the highly variable AOD (both temporally and spatially that occurs more frequently at high AOD) that violates the retrieval requirement of relatively spatially homogeneous AOD and resultant smooth sky radiance field over the entire range of angular distributions of sky radiance measurements. Another reason for the lack of almucantar retrievals is that the

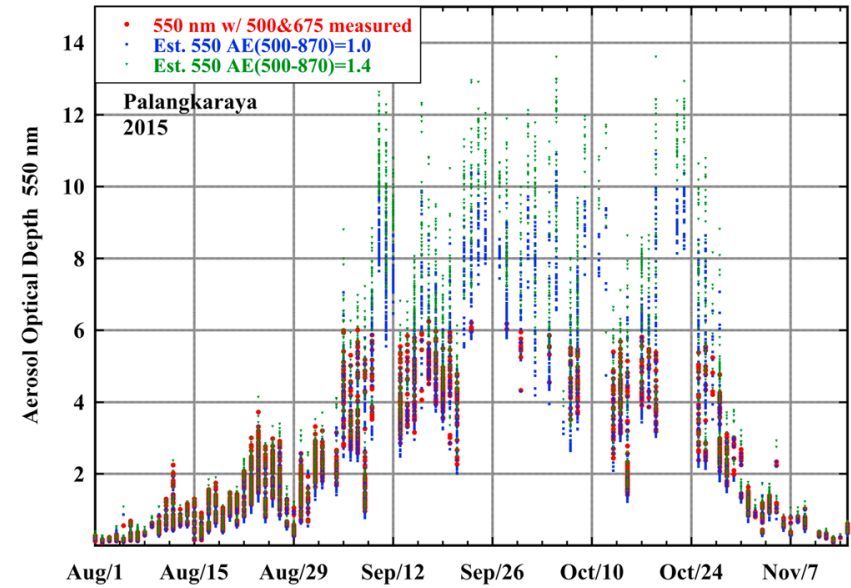

Figure 6. Time series of AOD at $550 \mathrm{~nm}$ at the Palangkaraya, Indonesia site from 1 August through 15 November 2015. Shown in red are AOD at $550 \mathrm{~nm}$ computed when measured values at 500 and $675 \mathrm{~nm}$ were available. Also shown are estimates of 550-nm AOD, utilizing the measured 870-nm AOD in conjunction with assumed Ångström exponents (500-870 nm) of 1.0 (blue) and 1.4 (green); see AE values at the highest AOD levels in Figure 5b. $\mathrm{AOD}=$ aerosol optical depth; $\mathrm{AE}=$ Ångström exponent. minimum SZA required for sufficient angular range of sky radiances is $50^{\circ}$, and the product of AOD * air mass often exceeded the maximum value of $\sim 7$ at $440 \mathrm{~nm}$. Therefore, the nearly complete attenuation of the solar signal in the short wavelength visible $(440 \mathrm{~nm})$ eliminated a required and critical retrieval channel. However, at both the Palangkaraya and Singapore sites, there were new model Cimel Sun-sky radiometers (Model-T) that have the capability to make a new type of sky radiance scan called the hybrid scan. This scan moves in both zenith and azimuth angles simultaneously, so is intermediate between the almucantar (fixed zenith angle) and principal plane scan (fixed azimuth angle). It has the advantages of the sky radiance homogeneity check and spatial averaging that the almucantar scan has (Torres et al., 2014) and also the advantage of sampling a large scattering angle range at much smaller SZAs, similar to the principal plane scan. Therefore, when AOD is extremely high as during this event, the hybrid scan, which allows for retrievals down to SZAs of $25^{\circ}$, results in many more 440-nm AOD observations available and therefore many more hybrid retrievals than possible from almucantar scans. For example, the AOD time series from 5 September 2015 at Palangkaraya (Figure 7) shows the shorter wavelength AOD values being sequentially eliminated as AOD* air mass exceeds the maximum AOD limit for Sun photometry. Note that all AOD data for this day failed to reach Level 2 in Version 2 database with only six points shown in Level 1. However, in Version 3, there were 71 instantaneous measurement 


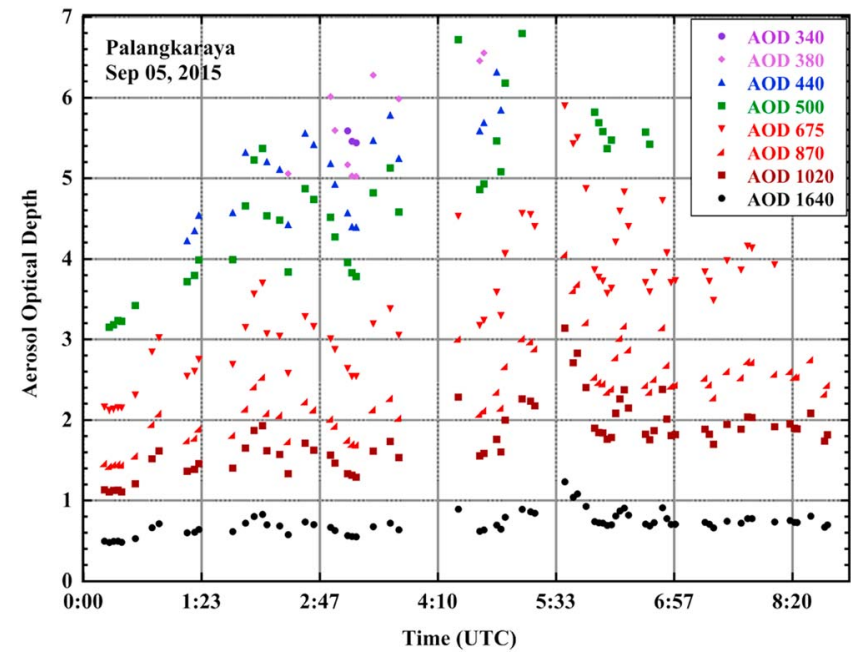

Figure 7. Time series of L2 cloud-screened AOD for all eight measured wavelengths on 1 day, 5 September 2015 at the Palangkaraya site. Note that the shorter wavelengths were sequentially attenuated at the largest optical air masses in the early morning and late afternoon (solar noon 4:25 UTC). The 340-nm direct Sun signal was nearly completely attenuated for all but three points at approximately 3:10 UTC. The only wavelengths with sufficient measured signal to measure accurate AOD for the entire day were $870,1,020$, and $1,640 \mathrm{~nm}$. AOD = aerosol optical depth. times for both Levels 1 and 2 although most spectra did not have the full wavelength complement of AOD. Note that only three measured spectra had the 340-nm AOD, while $440 \mathrm{~nm}$ had 22 points, and the three longest wavelengths $(870,1,020$, and $1,640 \mathrm{~nm})$ all had 71 points. The scale makes the longer wavelength AODs look flatter in Figure 7, when in fact, the percentage change from low to high values in AOD is similar for the 500- and 1,020-nm AODs. Both wavelengths show more than a doubling of AOD from lowest to highest measurements for times when both wavelengths are available.

Figure 8 shows both the hybrid and almucantar scan retrievals of 440$\mathrm{nm}$ SSA as a function of AOD at $440 \mathrm{~nm}$, for both the Palangkaraya and Singapore sites. At both sites, it is noted that for very high AOD at $440 \mathrm{~nm}$, there are many more retrievals made with the hybrid scan than the almucantar scan, approximately 3 times more retrievals when AOD $(440 \mathrm{~nm})>2$. The majority of the SSA values for AOD (440 $\mathrm{nm})>2$ fall within the $\sim 0.96$ to $\sim 0.99$ range, that is, very weakly absorbing particles. No significant trend with AOD was visible at high AOD, suggesting stability in both the aerosol population and in the retrieval itself.

Figure 9 shows the wavelength dependence of the SSA from 440 to $1,020 \mathrm{~nm}$ as measured at the Palangkaraya site during the 2015 biomass burning event. Shown are all Palangkaraya retrievals averaged for high aerosol loading conditions when AOD at $440 \mathrm{~nm}$ exceeded a value of 1.0, shown separately for both almucantar and hybrid scan retrievals. Also shown for comparison purposes are the V3 almucantar retrieval averages for high AOD (also average value for AOD[440] > 1) smoke events during the 2004 and 2005 summer drought years at the Bonanza Creek AERONET site in central Alaska (Eck et al., 2009). The multiyear spectral SSA averaged for two AERONET sites in Amazonia (Alta Floresta and ABRACOS Hill; Giles et al., 2012) affected by tropical rainforest forest burning are also shown. All Level 2 almucantar retrievals where AOD $(440 \mathrm{~nm})$ exceed 0.4 were averaged for both of the Amazonian sites. Note that all retrievals shown in Figure 9 are Version 3 Level 2 retrievals and therefore differ somewhat from the previously published Version 2 values. The spectral values of SSA in Singapore (not shown) for AOD $[440 \mathrm{~nm}]>1$ are within $\sim 0.003$ or less of those retrieved for Palangkaraya and the spectral dependence
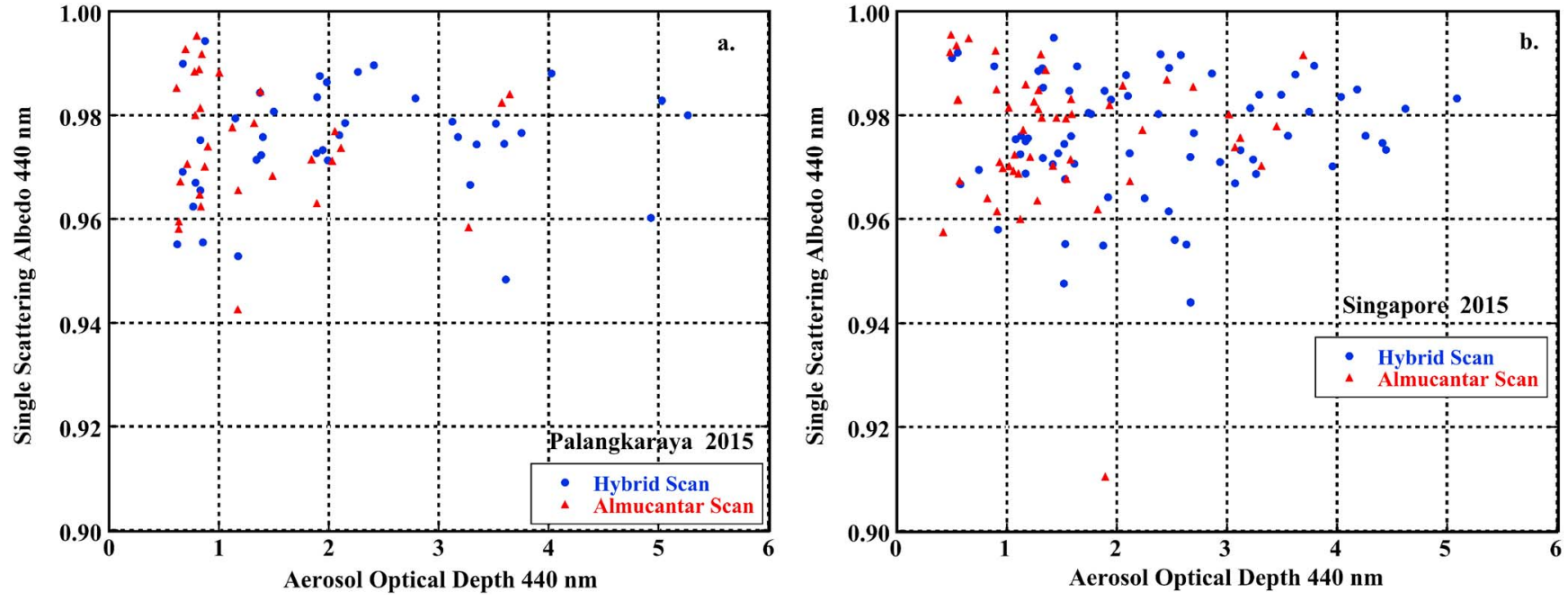

Figure 8. Retrieved aerosol single scattering albedo at $440 \mathrm{~nm}$ from 1 August through 15 November 2015 for the Aerosol Robotic Network sites at (a) Palangkaraya and (b) Singapore. Note the significantly larger number of retrievals made with the hybrid scans versus the almucantar sky scans, especially for aerosol optical depth $(440 \mathrm{~nm})$ greater than 2 . 


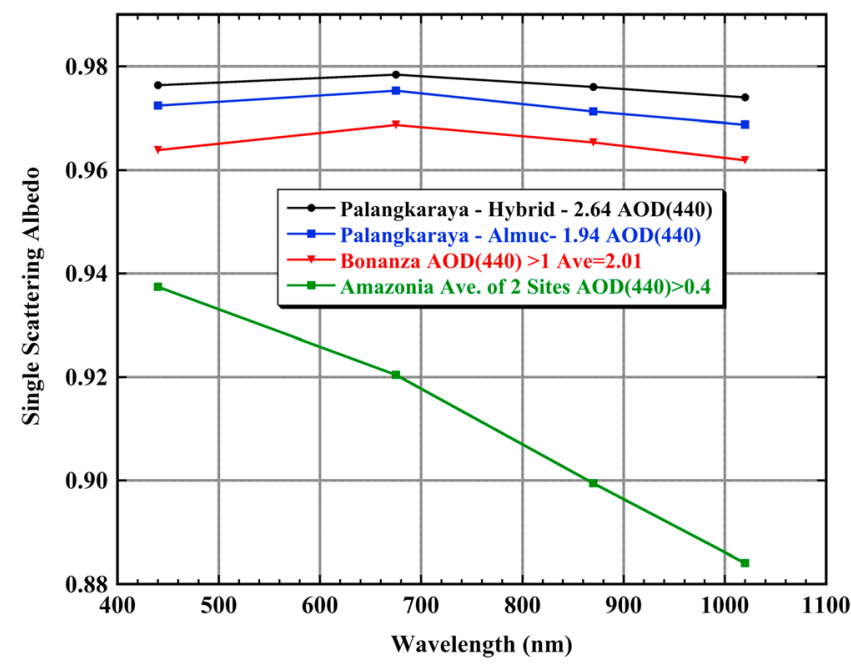

Figure 9. The spectral variation of aerosol single scattering albedo computed from Version 3 Level 2 sky radiance scan retrievals. Shown are the average values for Palangkaraya for all retrievals when AOD $(440 \mathrm{~nm})$ exceeded 1, both almucantar and hybrid scans. Also shown are almucantar retrievals for the Bonanza Creek, Alaska, site at AOD (440) $>1$ for the extensive burning seasons during the summers of 2004 and 2005, when there was significant burning of boreal region peat soils. The data for two sites in Amazonia (Alta Floresta and ABRACOS Hill, both in Brazil) that are located in tropical forest/pasture regions were averaged over multiple years for all observations where AOD $(440 \mathrm{~nm})$ exceeded 0.4. AOD = aerosol optical depth. is also essentially the same. The average SSA values at Palangkaraya show minimal wavelength dependence in this spectral range; spectral SSA retrieved at the Bonanza Creek site in central Alaska also exhibited similarly high SSA values as those at Palangkaraya and also with very small wavelength dependence. Biomass burning in Alaska in 2004 and 2005 also included significant peat burning (Turquety et al., 2007). Peat fuel burns nearly entirely by smoldering phase combustion and therefore produces extremely little black carbon, which for biomass burning smoke is the main absorbing component in the visible and near-infrared wavelengths (Lewis et al., 2008). In fact, measurements of particle SSA from burning of Indonesian peat in the laboratory by Chand et al. (2005) was 0.99 in the midvisible (540 nm). Pokhrel et al. (2016) also found the same value of SSA at 0.99 at both 532 and $660 \mathrm{~nm}$ for Indonesian peat smoke particles. Also, likely contributing to the weak absorption of particles produced from peat burning is the high sulfur content of Indonesian peat resulting in part from the sulfur emissions of numerous volcanoes in the region (Langmann \& Graf, 2003). Ikegami et al. (2001) measured high sulfur dioxide and sulfate levels, relative to other biomass burning regions, for smoke from Kalimantan, Indonesia, in the major peat burning year of 1997. Brown carbon is also produced in smoldering phase combustion, and this results in spectral aerosol absorption in addition to black carbon; however, the strongest absorption for brown carbon is in the UV wavelengths and short wavelength visible (Mok et al., 2016).

Figure 10 is similar to Figure 8 but instead showing the retrieved volume median radius as a function of AOD at $440 \mathrm{~nm}$, for both almucantar and hybrid scan retrievals and for both the Palangkaraya and Singapore sites. At both sites, the fine-mode radius of the biomass burning smoke increased from averages of $\sim 0.16-0.18 \mu \mathrm{m}$ for AOD less than 0.5 to radius values greater than $0.20 \mu \mathrm{m}$ when AOD was greater than 1, with maximum radius values exceeding $0.26 \mu \mathrm{m}$ at some of the highest AOD level days in Palangkaraya, to greater than $0.30 \mu \mathrm{m}$ at the Singapore site. This trend of increasing particle radius with increasing AOD was also observed in central Alaska during the summers of 2004 and 2005 (Eck et al., 2009), with similar particle radii from AERONET retrievals in that region. The increase in radius as a function of increasing AOD may be due in part to increased coagulation rates as aerosol concentrations increase (Colarco et al., 2004; Reid \& Hobbs,
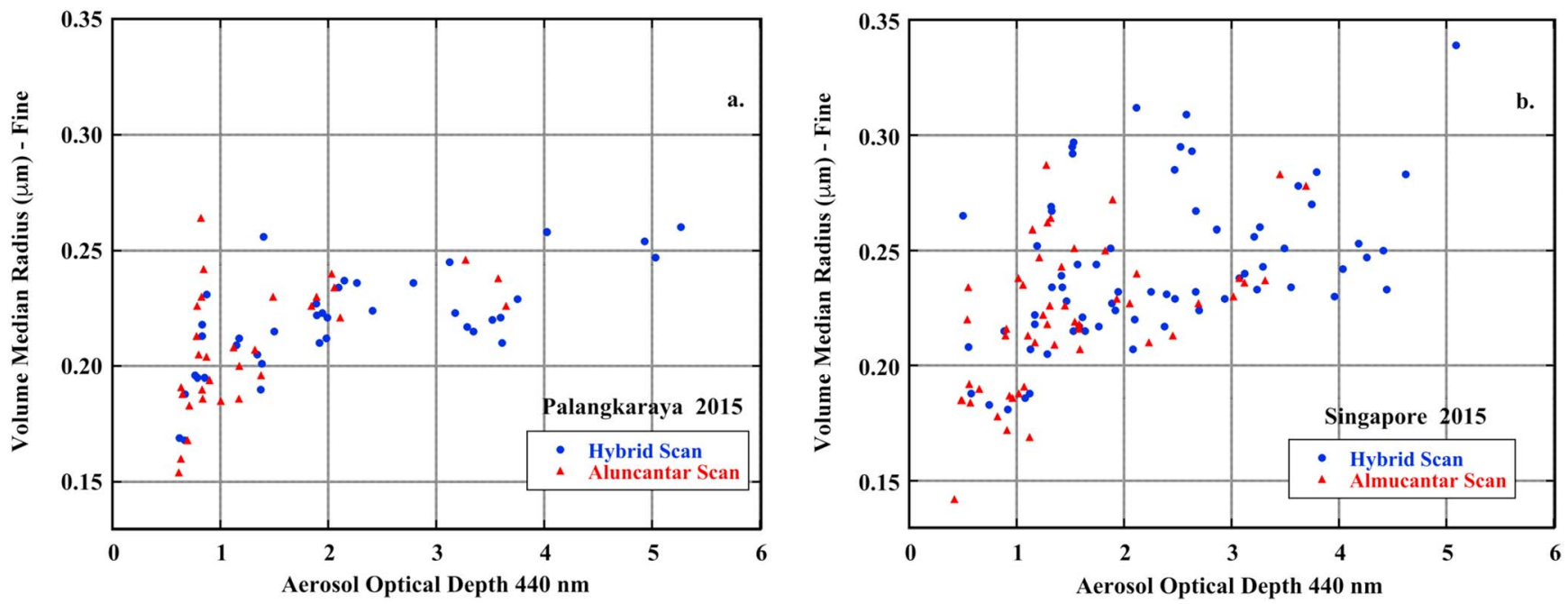

Figure 10. Retrieved fine-mode volume median radius from 1 August through 15 November 2015 for the Aerosol Robotic Network sites at (a) Palangkaraya and (b) Singapore. Note the significantly larger number of retrievals made with the hybrid scans versus the almucantar sky scans, especially for AOD (440 nm) greater than 2 . 


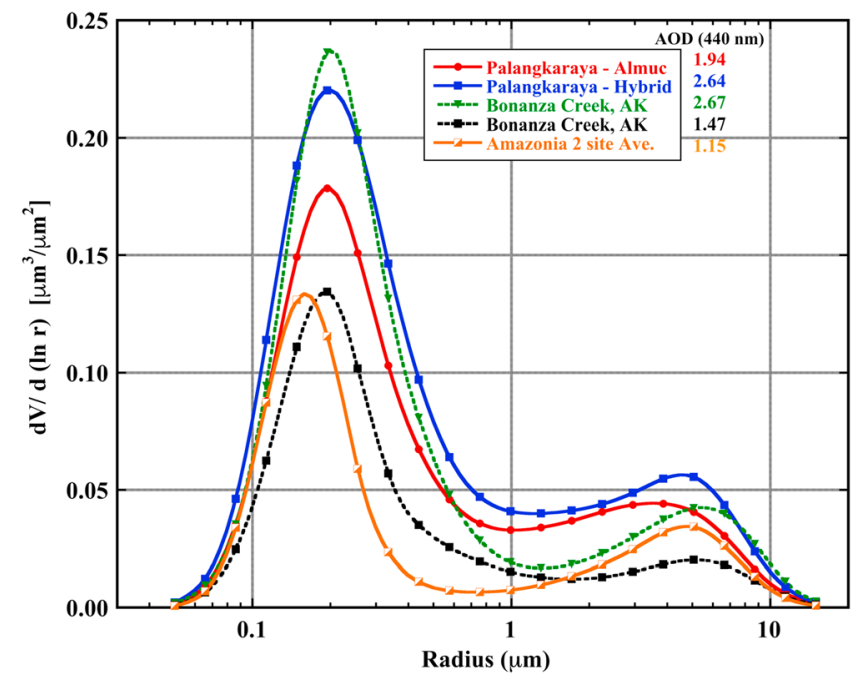

Figure 11. Comparison of Version 3 AERONET size distribution retrievals from almucantar sky radiance scans at three sites, also including hybrid scan retrievals at Palangkaraya. Data at the Palangkaraya, Indonesia, site were averaged for all retrievals where AOD $(440 \mathrm{~nm})$ exceeded 1.0. Retrievals at the Bonanza Creek, Alaska, site were from data in 2004 and 2005 when extensive burning occurred, including significant peat burning due to dry conditions. The Bonanza Creek data for average

AOD $(440)=1.47$ were from all data where $1<\operatorname{AOD}(440)<2$, while for $\operatorname{AOD}(440)=2.67$, the data were averaged from all retrievals where AOD exceeded 2.0. Data shown for Amazonia are from two sites combined in Brazil, Alta Floresta and ABRACOS Hill, for all Level 2 data averaged for all years of monitoring. AOD = aerosol optical depth.
1998), as was also suggested by the trend of decreasing AE as AOD increased (see Figure $5 \mathrm{~b}$ ). The larger fine-mode radius values retrieved at Singapore may therefore be due to longer aerosol aging times and greater time for coagulation during plume transport since Singapore is located much farther from the Indonesian fire source regions, while Palangkaraya is located directly in one of the biomass burning regions. The correlation between SSA and fine-mode radius is relatively weak at both sites, explaining $\sim 11 \%$ of the variance (all wavelengths SSA) at Palangkaraya and only $1 \%$ of the variance at Singapore. This suggests that the high SSA at both sites is driven primarily by low black carbon content and not by particle size.

The retrieved size distributions for selected levels of AOD for the Palangkaraya site as compared to the Bonanza Creek, Alaska, and Amazonia sites are shown in Figure 11. Note the similarity in the finemode size distribution for both the Bonanza Creek and Palangkaraya sites when AOD at $440 \mathrm{~nm}$ was extremely high at $\sim 2.6$. Also, the fine-mode distributions are quite wide for these two sites that had significant amounts of peat fuel burning. The fine mode extends to a maximum particle volume radius of $0.99 \mu \mathrm{m}$ for Palangkaraya at an averaged AOD $(440 \mathrm{~nm})$ of 2.64. This contrasts with a much narrower size distribution for the Amazonia sites smoke size distributions, where the fine-mode inflection is $\sim 0.6 \mu \mathrm{m}$. Smoke at the Amazonian sites resulted from combustion of both pasture grass fuels in both flaming and smoldering phases and tropical rain forest woody fuels in primarily the smoldering combustion phase (Ferek et al., 1998; Reid \& Hobbs, 1998). However, the peat fuel combustion occurs nearly exclusively in the smoldering phase and may also produce some much larger particles. Chakrabarty et al. (2016) show transmission electron microscopy images of smoke particles from laboratory combustion of boreal region (Alaska and Siberia) peat samples, with some very large particles of radius 0.65 and 1.75 microns, while other particles were as small as $0.1-$ to $\sim 0.2-\mu \mathrm{m}$ radius. Therefore, it appears that peat combustion produces some very large particles, even without coagulation occurring over relatively long time intervals. However, coagulation at high concentrations also likely contributed to increased fine-mode particle radius as AOD increased.

\subsection{Estimation of the Percentage of Peat Burning in Southern Borneo}

It is clear from the very high values of the AERONET retrievals of SSA at the Palangkaraya site (source region) and Singapore site (downwind transport) that the smoke from this biomass burning event had very little black carbon content. As previously mentioned, this is primarily due the fact that the smoldering phase of combustion dominates peat burning, and therefore, very little black carbon is produced. Additionally independent analyses and ground measurements have concluded that peat burning was the dominant fuel burned in southern Borneo and Sumatra during this event in 2015 (Huijnen et al., 2016). Here we utilize the AERONET retrievals of SSA along with some assumptions on peat smoke SSA and the SSA of the other types of fuel burned in order to estimate the percentage contribution of peat fuel burning to the total smoke AOD emitted. As previously mentioned, two independent laboratory measurement studies of Indonesian peat fuel particle absorption showed them to be almost nonabsorbing, with SSA of $\sim 0.99$ at 532 to $660 \mathrm{~nm}$ (Chand et al., 2005; Pokhrel et al., 2016). Therefore, we make the assumption that an SSA value of 0.99 for Indonesian peat smoke particles is relatively robust. We then need to make an assumption about the SSA of the nonpeat fuels that are burned in the region of the Palangkaraya site. Since peat fuels are burned to varying degrees in all years in this region, we cannot utilize this regional data to estimate the SSA of the other vegetation types burned since the smoke particles here are always produced from a mixture of combustion of various vegetation fuel types including peat. Therefore, we select measurements of SSA from AERONET retrievals made in a different tropical rainforest forest region. The biomass burning fuel in southern Amazonia, Brazil, is from a combination of forest clearing burning, which is 
primarily wood, and pasture burning fuel, which is primarily grass (see Reid \& Hobbs, 1998; Reid et al., 2005 , for in depth discussions). The smoke properties in the forested areas of this region are dominated by woody fuel combustion since the biomass of the wood (trunks and branches) is much higher than for pasture grass, and additionally, there are no peat soils that have burned in southern Amazonia. The average spectral variation of SSA averaged for two sites in southern Amazonia from Giles et al. (2012) updated with Version 3 data is shown in Figure 9. We therefore estimate the percentage peat fuel burned from the following equation:

$$
\text { Measured SSA }=\text { Peat SSA }(x)+\text { Other Fuel SSA }(1-x),
$$

where $x$ is the fraction of AOD contributed from peat burning aerosols.

Using equation (1) and the assumed value of 0.99 for peat SSA, spectrally varying Other Fuel SSA from the southern Amazonia forest region sites and the measured value of SSA at Palangkaraya, we can solve for $x$, the fraction of peat burning that contributed to total AOD. We computed $x$ for three wavelengths, 675, 870 , and 1,020 $\mathrm{nm}$, since there may be some complication at $440 \mathrm{~nm}$ due to additional brown carbon absorption. The measured values of SSA at Palangkaraya for these three wavelengths as shown in Figure 9 were utilized in equation (1). The percentage peat fuel contribution computed from this methodology varied from $79 \%$ at $675 \mathrm{~nm}$ to $80 \%$ at $1,020 \mathrm{~nm}$ from the averaged almucantar scans retrievals (15 retrievals). The same methodology applied to the averaged hybrid scan retrievals (30 retrievals, see Figure 9) yielded estimates of the percentage of peat fuel contribution ranging from $83 \%$ utilizing $675-\mathrm{nm}$ data to $85 \%$ at $1,020 \mathrm{~nm}$. Estimates of the percentage peat combustion for this 2015 Indonesian biomass burning event were also made by Kaiser et al. (2016) by (1) using an improved peat map in the Global Fire Assimilation System and (2) analyzing the observed diurnal cycle of the fire activity from satellite as represented in a new development for Global Fire Assimilation System. They estimated that the percentage of carbon emitted by peat burning from the 2015 event was $\sim 83 \%$, very similar to the value of peat burned contribution to AOD that we estimated from AERONET retrievals of SSA. Utilizing completely different methodology, Wiggins et al. (2018) also estimated that the contribution of peat burning to total vegetation combustion for aerosol was $\sim 85 \%$ in 2015 , from radiocarbon content analysis of fine-mode particles in Singapore. Additionally, Page et al. (2002) analyzed satellite images in conjunction with ground-based measurements and survey data and estimated that for central Kalimantan in 1997 (an even larger biomass burning event than 2015) that peat burning contributed $\sim 80-85 \%$ to the total carbon emitted with the remainder coming from combustion of the overlying vegetation. Therefore, it seems that peat burning during both major El Niño events in this region (1997 and 2015) may have resulted in peat combustion contributing $\sim 80-85 \%$ of the total emissions of both carbon and particulates.

\section{Summary and Conclusions}

The aerosol optical characteristics of smoke emitted from the massive Indonesian biomass burning episode in September through October 2015 was investigated through measurements made by AERONET Sun-sky radiometers in Indonesia and Singapore. Analysis of the measured spectral AOD and retrieved aerosol size distributions and SSA are presented with the major findings summarized below.

1. The new Cimel Model-T instrument in conjunction with AERONET Version 3 data algorithm capabilities allowed for much more robust monitoring of the extremely high biomass burning AOD event in Indonesia in 2015 than would have been possible with the previously available Version 2 database.

2. The Cimel capability to track the Sun in the near-infrared wavelengths was utilized to measure AOD at 870-, 1,020-, and 1,640-nm wavelengths when the UV and visible wavelengths were completely attenuated due to optical air mass * AOD exceeding 7, additionally when AE (870-1,020 nm) exceeded 1.3. This is a new data feature of AERONET Version 3 AOD data set. For this very high AOD event the new V3 algorithm allowed for maximum AOD values at $870 \mathrm{~nm}$ that were twice as high as those measured in V2, additionally V3 provided many more days of AOD compared to V2 during the intervals of highest AOD occurrence. This may have significant implications for estimates of surface PM2.5 from satellite, radiative forcing, and simulation model validation for major events with extreme AOD levels.

3. AOD at $550 \mathrm{~nm}$ was estimated to reach maximum values of $\sim 11$ to $\sim 13$ during this event in the major peat burning region of southern Borneo (Palangkaraya site). These are the highest AOD ever estimated from 
AERONET data, and we have no knowledge of smoke AOD values this high having been previously reported in the scientific literature.

4. Retrievals of midvisible AOD from the standard MODIS algorithms (DT, DB, and MAIAC algorithms) consistently underestimated the magnitude of the AOD in the peak burning region (Palangkaraya site) during this event and also did not make retrievals on many high AOD days. However, the special high AOD event algorithm recently introduced and described by Shi et al. (2019) overcomes many of these shortcomings in MODIS satellite AOD retrieval for this particular event. Likewise, the new VIIRS DB greatly increases coverage in these heavy-smoke situations, although the retrievals are inherently more uncertain in such extreme environments.

5. The new hybrid sky radiance scan available only in the new model Cimel Model-T Sun-sky radiometers allowed for the retrieval of aerosol refractive indices and size distributions at higher AOD levels due to retrieval capability at smaller SZAs when the 440-nm signal is not completely attenuated. These hybrid scan retrievals are also a new feature of the AERONET Version 3 data set. This enhanced instrumental capability was very important for this particularly high AOD event.

6. The SSA of the Indonesian biomass burning aerosol at extremely high AOD in 2015 was very high, averaging $\sim 0.975$ with little wavelength dependence, and the volume median fine-mode radius was very large $\sim 0.20$ to $0.30 \mu \mathrm{m}$ (in comparison to typical biomass burning values of $\sim 0.13$ to $0.17 \mu \mathrm{m}$ ), both consistent with in situ measurements of smoke from peat fuel burning (smoldering combustion).

7. The percentage of aerosol emissions from peat combustion during the 2015 Indonesian burning event was estimated to be $\sim 80-85 \%$, based on AERONET retrievals of SSA made in Palangkaraya in southern Borneo plus assumptions of the SSA for the peat smoke and of the above ground vegetation burned. This is consistent with an estimated contribution percentage of peat combustion to total carbon emitted of $\sim 83 \%$ by Kaiser et al. (2016) and also for 2015 in Indonesia.

Acknowledgments

We thank Hal Maring (NASA Headquarters) and Steve Platnik (NASA GSFC) for their continuing long-term commitment and support for the AERONET project. MODIS aerosol data are available freely from https:// laadsweb.nascom.nasa.gov. More information about Deep Blue is available at https://deepblue.gsfc.nasa. gov, and more information about Dark Target at https://darktarget.gsfc.nasa. gov. J. S Reid's contributions were provided by the Office of Naval Research Code 322 (N0001418WX00442).

\section{References}

Aouizerats, B., van der Werf, G. R., Balasubramanian, R., \& Betha, R. (2015). Importance of transboundary transport of biomass burning emissions to regional air quality in Southeast Asia during a high fire event. Atmospheric Chemistry and Physics, 15(1), 363-373. https:// doi.org/10.5194/acp-15-363-2015

Barreto, Á., Cuevas, E., Granados-Muñoz, M.-J., Alados-Arboledas, L., Romero, P. M., Gröbner, J., et al. (2016). The new sun-sky-lunar Cimel CE318- T multiband photometer - a comprehensive performance evaluation. Atmospheric Measurement Techniques, 9(2), 631-654. https://doi.org/10.5194/amt-9-631-2016

Chakrabarty, R. K., Gyawali, M., Yatavelli, R. L. N., Pandey, A., Watts, A. C., Knue, J., et al. (2016). Brown carbon aerosols from burning of boreal peatlands: Microphysical properties, emission factors, and implications for direct radiative forcing. Atmospheric Chemistry and Physics, 16, 3033-3040. https://doi.org/10.5194/acp-16-3033-2016

Chand, D., Schmid, O., Gwaze, P., Parmar, R. S., Helas, G., Zeromskiene, K., et al. (2005). Laboratory measurements of smoke optical properties from the burning of Indonesian peat and other types of biomass. Geophysical Research Letters, 32, L12819. https://doi.org/ 10.1029/2005GL022678

Chew, B. N., Campbell, J. R., Reid, J. S., Giles, D. M., Welton, E. J., Salinas, S. V., \& Liew, S. C. (2011). Tropical cirrus cloud contamination in sun photometer data. Atmospheric Environment, 45(37), 6724-6731. https://doi.org/10.1016/j.atmosenv.2011.08.017

Clarke, A. D., Howell, S., Quinn, P. K., Bates, T. S., Ogren, J. A., Andrews, E., et al. (2002). INDOEX aerosol: A comparison and summary of chemical, microphysical, and optical properties observed from land, ship, and aircraft. Journal of Geophysical Research, 107(D19), 8033. https://doi.org/10.1029/2001JD000572

Colarco, P. R., Schoeberl, M. R., Doddridge, B. G., Marufu, L. T., Torres, O., \& Welton, E. J. (2004). Transport of smoke from Canadian forest fires to the surface near Washington, D.C.: Injection height, entrainment, and optical properties. Journal of Geophysical Research, 109, D06203. https://doi.org/10.1029/2003JD004248

Crippa, P., Castruccio, S., Archer-Nicholls, S., Lebron, G. B., Kuwata, M., Thota, A., et al. (2016). Population exposure to hazardous air quality due to the 2015 fires in equatorial Asia. Scientific Reports, 6(1), 1-9. https://doi.org/10.1038/srep37074

Dubovik, O., \& King, M. D. (2000). A flexible inversion algorithm for the retrieval of aerosol optical properties from Sun and sky radiance measurements. Journal of Geophysical Research, 105(D16), 20,673-20,696. https://doi.org/10.1029/2000JD900282

Dubovik, O., Sinyuk, A., Lapyonok, T., Holben, B. N., Mishchenko, M., Yang, P., et al. (2006). The application of spheroid models to account for aerosol particle nonsphericity in remote sensing of desert dust. Journal of Geophysical Research, 111, D11208. https://doi.org/ 10.1029/2005JD006619

Dubovik, O., Smirnov, A., Holben, B. N., King, M. D., Kaufman, Y. J., Eck, T. F., \& Slutsker, I. (2000). Accuracy assessments of aerosol optical properties retrieved from AERONET Sun and sky-radiance measurements. Journal of Geophysical Research, 105(D8), 9791-9806. https://doi.org/10.1029/2000JD900040

Eck, T. F., Holben, B. N., Reid, J. S., Dubovik, O., Smirnov, A., O'Neill, N. T., et al. (1999). Wavelength dependence of the optical depth of biomass burning, urban, and desert dust aerosols. Journal of Geophysical Research, 104(D24), 31,333-31,349. https://doi.org/10.1029/ 1999JD900923

Eck, T. F., Holben, B. N., Reid, J. S., Sinyuk, A., Hyer, E. J., O'Neill, N. T., et al. (2009). Optical properties of boreal region biomass burning aerosols in central Alaska and seasonal variation of aerosol optical depth at an Arctic coastal site. Journal of Geophysical Research, 114, D11201. https://doi.org/10.1029/2008JD010870 
Eck, T. F., Holben, B. N., Sinyuk, A., Pinker, R. T., Goloub, P., Chen, H., et al. (2010). Climatological aspects of the optical properties of fine/coarse mode aerosol mixtures. Journal of Geophysical Research, 115, D19205. https://doi.org/10.1029/2010JD014002

Ferek, R. J., Reid, J. S., Hobbs, P. V., Blake, D. R., \& Liousse, C. (1998). Emission factors of hydrocarbons, halocarbons, trace gases and particles from biomass burning in Brazil. Journal of Geophysical Research, 103(D24), 32,107-32,118. https://doi.org/10.1029/98JD00692 Fernandes, K., Verchot, L., Baethgen, W., Gutierrez-Velez, V., Pinedo-Vasquez, M., \& Martius, C. (2017). Heightened fire probability in Indonesia in non-drought conditions: The effect of increasing temperatures. Environmental Research Letters, 12(5), 054002. https://doi. org/10.1088/1748-9326/aa6884

Field, R. D., van der Werf, G. R., Fanin, T., Fetzer, E. J., Fuller, R., Jethva, H., et al. (2016). Indonesian fire activity and smoke pollution in 2015 show persistent nonlinear sensitivity to El Niño-induced drought. Proceedings of the National Academy of Sciences of the United States of America, 113(33), 9204-9209. https://doi.org/10.1073/pnas.1524888113

Field, R. D., van der Werf, G. R., \& Shen, S. S. P. (2009). Human amplification of drought-induced biomass burning in Indonesia since 1960 Nature Geoscience, 2(3), 185-188. https://doi.org/10.1038/ngeo443

Giglio, L., Descloitres, J., Justice, C. O., \& Kaufman, Y. J. (2003). An enhanced contextual fire detection algorithm for MODIS. Remote Sensing of Environment, 87(2-3), 273-282. https://doi.org/10.1016/S0034-4257(03)00184-6

Giles, D. M., Holben, B. N., Eck, T. F., Sinyuk, A., Smirnov, A., Slutsker, I., et al. (2012). An analysis of AERONET aerosol absorption properties and classifications representative of aerosol source regions. Journal of Geophysical Research, 117, D17203. https://doi.org/ 10.1029/2012JD018127

Giles, D. M., Sinyuk, A., Sorokin, M. G., Schafer, J. S., Smirnov, A., Slutsker, I., et al. (2019). Advancements in the Aerosol Robotic Network (AERONET) Version 3 database-Automated near-real-time quality control algorithm with improved cloud screening for Sun photometer aerosol optical depth (AOD) measurements. Atmospheric Measurement Techniques, 12, 169-209. https://doi.org/10.5194/amt-12169-2019

Glauber, A. J., Gunawan, I., Adriani, M., Moyer, S., Ahmad, M., Kendrick, A., et al. (2015). Indonesia economic quarterly (IEQ), World Bank, Jakarta. December 2015.

Gupta, P., Levy, R. C., Mattoo, S., Remer, L. A., \& Munchak, L. A. (2016). A surface reflectance scheme for retrieving aerosol optical depth over urban surfaces in MODIS Dark Target retrieval algorithm. Atmospheric Measurement Techniques, 9(7), 3293-3308. https://doi.org/ 10.5194/amt-9-3293-2016

Ham, Y.-G., \& Kug, J.-S. (2016). ENSO amplitude changes due to greenhouse warming in CMIP5: Role of mean tropical precipitation in the twentieth century. Geophysical Research Letters, 43, 422-430. https://doi.org/10.1002/2015GL066864

Heil, A., Langmann, B., \& Aldrian, E. (2007). Indonesian peat and vegetation fire emissions: Study on factors influencing large-scale smoke haze pollution using a regional atmospheric chemistry model. Mitigation and Adaptation Strategies for Global Change, 12(1), 113-133. https://doi.org/10.1007/s11027-006-9045-6

Holben, B. N., Eck, T. F., Slutsker, I., Smirnov, A., Sinyuk, A., Schafer, J., et al. (2006). AERONET's version 2.0 quality assurance criteria. Remote Sensing of Atmosphere and Clouds, Proceedings of SPIE - The International Society for Optical Engineering, 6408, 64080Q. https:// doi.org/10.1117/12.706524

Holben, B. N., Eck, T. F., Slutsker, I., Tanre, D., Buis, J. P., Setzer, A., et al. (1998). AERONET—A federated instrument network and data archive for aerosol characterization. Remote Sensing of Environment, 66(1), 1-16. https://doi.org/10.1016/S0034-4257(98)00031-5

Hsu, N. C., Lee, J., Sayer, A. M., Kim, W., Bettenhausen, C., \& Tsay, S.-C. (2019). VIIRS Deep Blue aerosol products over land: Extending the EOS long-term aerosol data records. Journal of Geophysical Research: Atmospheres, 124. https://doi.org/10.1029/2018JD029688

Huijnen, V., Wooster, M. J., Kaiser, J. W., Gaveau, D. L. A., Flemming, J., Parrington, M., et al. (2016). Fire carbon emissions over maritime southeast Asia in 2015 largest since 1997. Scientific Reports, 6(1), 26886. https://doi.org/10.1038/srep26886

Hyer, E. J., Reid, J. S., Prins, E. M., Hoffman, J. P., Schmidt, C. C., Miettinen, J. I., \& Giglio, L. (2013). Different views of fire activity over Indonesia and Malaysia from polar and geostationary satellite observations. Atmospheric Research, 122, 504-519. https://doi.org/ 10.1016/j.atmosres.2012.06.011

Ikegami, M., Okada, K., Zaizen, Y., Makino, Y., Jensen, J. B., Gras, J. L., \& Harjanto, H. (2001). Very high weight ratios of S/K in individual haze particles over Kalimantan during the 1997 Indonesian forest fires. Atmospheric Environment, 35(25), 4237-4243. https://doi.org/ $10.1016 / \mathrm{S} 1352-2310(01) 00247-3$

Johnson, B. T., \& Osborne, S. R. (2011). Physical and optical properties of mineral dust aerosol measured by aircraft during the GERBILS campaign. Quarterly Journal of the Royal Meteorological Society, 137(658), 1117-1130. https://doi.org/10.1002/qj.777

Kaiser, J. W., van der Werf, G. R., \& Heil, A. (2016). Global climate biomass burning in "State of the climate in 2015". Bulletin of the American Meteorological Society, 97(8), S1-S275. https://doi.org/10.1175/2016BAMSStateoftheClimate.1

Kusumaningtyas, S. D. A., \& Aldrian, E. (2016). Impact of the June 2013 Riau province Sumatera smoke haze event on regional air pollution. Environmental Research Letters, 11(7), 075007. https://doi.org/10.1088/1748-9326/11/7/075007

Kusumaningtyas, S. D. A., Aldrian, E., Arif Rahman, M., \& Sopaheluwakan, A. (2016). Aerosol properties in central Kalimantan due to peatland fire. Aerosol and Air Quality Research, 16(11), 2757-2767. https://doi.org/10.4209/aaqr.2015.07.0451

Langmann, B., \& Graf, H. F. (2003). Indonesian smoke aerosols from peat fires and the contribution from volcanic sulfur emissions. Geophysical Research Letters, 30(11), 1547. https://doi.org/10.1029/2002GL016646

Leahy, L. V., Anderson, T. L., Eck, T. F., \& Bergstrom, R. W. (2007). A synthesis of single scattering albedo of biomass burning aerosol over southern Africa during SAFARI 2000. Geophysical Research Letters, 34, L12814. https://doi.org/10.1029/2007GL029697

Levy, R. C., Mattoo, S., Munchak, L. A., Remer, L. A., Sayer, A. M., Patadia, F., \& Hsu, N. C. (2013). The Collection 6 MODIS aerosol products over land and ocean. Atmospheric Measurement Techniques, 6(11), 2989-3034. https://doi.org/10.5194/amt-6-2989-2013

Lewis, K., Arnott, W. P., Moosmuller, H., \& Wold, C. E. (2008). Strong spectral variation of biomass smoke light absorption and single scattering albedo observed with a novel dual-wavelength photoacoustic instrument. Journal of Geophysical Research, 113, D16203. https://doi.org/10.1029/2007JD009699

Lin, N.-H., Tsay, S.-C., Maring, H. B., Yen, M.-C., Sheu, G.-R., Wang, S.-H., et al. (2013). An overview of regional experiments on biomass burning aerosols and related pollutants in Southeast Asia: From BASE-ASIA and the Dongsha Experiment to 7-SEAS. Atmospheric Environment, 78, 1-19. https://doi.org/10.1016/j.atmosenv.2013.04.066

Lyapustin, A., Wang, Y., Korkin, S., \& Huang, D. (2018). MODIS Collection 6 MAIAC algorithm. Atmospheric Measurement Techniques, 11(10), 5741-5765. https://doi.org/10.5194/amt-11-5741-2018

Miettinen, J., Hooijer, A., Vernimmen, R., Liew, S. C., \& Page, S. E. (2017). From carbon sink to carbon source: Extensive peat oxidation in insular Southeast Asia since 1990. Environmental Research Letters, 12(2), 024014. https://doi.org/10.1088/1748-9326/aa5b6f

Miettinen, J., Shi, C., \& Liew, S. C. (2017). Fire distribution in Peninsular Malaysia, Sumatra and Borneo in 2015 with special emphasis on peatland fires. Environmental Management, 60(4), 747-757. https://doi.org/10.1007/s00267-017-0911-7 
Mok, J., Krotkov, N. A., Arola, A., Torres, O., Jethva, H., Andrade, M., et al. (2016). Impacts of brown carbon from biomass burning on surface UV and ozone photochemistry in the Amazon Basin. Scientific Reports, 6(1), 36940. https://doi.org/10.1038/srep36940

Nichol, J. (1998). Smoke haze in Southeast Asia: A predictable recurrence. Atmospheric Environment, 32(14-15), 2715-2716. https://doi.org/ 10.1016/S1352-2310(98)00086-7

Page, S. E., \& Hooijer, A. (2016). In the line of fire: The peatlands of Southeast Asia. Philosophical Transactions of the Royal Society B, 371(1696), 20150176. https://doi.org/10.1098/rstb.2015.0176

Page, S. E., Siegert, F., Rieley, J. O., Boehm, H.-D. V., Jaya, A., \& Limin, S. (2002). The amount of carbon released from peat and forest fires in Indonesia during 1997. Nature, 420(6911), 61-65. https://doi.org/10.1038/nature01131

Pan, X., Chin, M., Ichoku, C., \& Field, R. (2018). Connecting Indonesian fires and drought with the type of El Niño and phase of the Indian Ocean dipole during 1979-2016. Journal of Geophysical Research: Atmospheres, 123, 7974-7988. https://doi.org/10.1029/2018JD028402

Pokhrel, R. P., Wagner, N. L., Langridge, J. M., Lack, D. A., Jayarathne, T., Stone, E. A., et al. (2016). Parameterization of single-scattering albedo (SSA) and absorption Ångström exponent (AAE) with EC/OC for aerosol emissions from biomass burning. Atmospheric Chemistry and Physics, 16(15), 9549-9561. https://doi.org/10.5194/acp-16-9549-2016

Pueschel, R. F., Russell, P. B., Allen, D. A., Ferry, G. V., Snetsinger, K. G., Livingston, J. M., \& Verma, S. (1994). Physical and optical properties of the Pinatubo volcanic aerosol: Aircraft observations with impactors and a Sun-tracking photometer. Journal of Geophysical Research, 99(D6), 12,915-12,922. https://doi.org/10.1029/94JD00621

Reid, J. S., Brooks, B., Crahan, K. K., Hegg, D. A., Eck, T. F., O'Neill, N., et al. (2006). Reconciliation of coarse mode sea-salt aerosol particle size measurements and parameterizations at a subtropical ocean receptor site. Journal of Geophysical Research, 111(D2), D02202. https://doi.org/10.1029/2005JD006200

Reid, J. S., Eck, T. F., Christopher, S. A., Koppmann, R., Dubovik, O., Eleuterio, D. P., et al. (2005). A review of biomass burning emissions part III: Intensive optical properties of biomass burning particles. Atmospheric Chemistry and Physics, 5(3), 827-849. https://doi.org/ 10.5194/acp-5-827-2005

Reid, J. S., \& Hobbs, P. V. (1998). Physical and optical properties of young smoke from individual biomass fires in Brazil. Journal of Geophysical Research, 103(D24), 32,013-32,030. https://doi.org/10.1029/98JD00159

Reid, J. S., Hyer, E. J., Johnson, R., Holben, B. N., Yokelson, R. J., Zhang, J., et al. (2013). Observing and understanding the Southeast Asian aerosol system by remote sensing: An initial review and analysis for the Seven Southeast Asian Studies (7SEAS) program. Atmospheric Research, 122, 403-468. https://doi.org/10.1016/j.atmosres.2012.06.005

Reid, J. S., Reid, E. A., Walker, A., Piketh, S., Cliff, S., Al Mandoos, A., et al. (2008). Dynamics of southwest Asian dust particle size characteristics with implications for global dust research. Journal of Geophysical Research, 113, D14212. https://doi.org/10.1029/ 2007JD009752

Sayer, A. M., Hsu, N. C., Bettenhausen, C., \& Jeong, M.-J. (2013). Validation and uncertainty estimates for MODIS Collection 6 "Deep Blue" aerosol data. Journal of Geophysical Research: Atmospheres, 118, 7864-7872. https://doi.org/10.1002/jgrd.50600

Schafer, J. S., Eck, T. F., Holben, B. N., Thornhill, K. L., Anderson, B. E., Sinyuk, A., et al. (2014). Intercomparison of aerosol single scattering albedo derived from AERONET surface radiometers and LARGE in situ aircraft profiles during the 2011 DRAGON-MD and DISCOVER-AQ experiments. Journal of Geophysical Research: Atmospheres, 119, 7439-7452. https://doi.org/10.1002/2013JD021166

Schmid, B., Michalsky, J., Halthore, R., Beauharnois, M., Harrison, L., Livingston, J., et al. (1999). Comparison of aerosol optical depth from four solar radiometers during the fall 1997 ARM intensive observation period. Geophysical Research Letters, 26(17), 2725-2728. https:// doi.org/10.1029/1999GL900513

Sessions, W. R., Reid, J. S., Benedetti, A., Colarco, P. R., da Silva, A., Lu, S., et al. (2015). Development towards a global operational aerosol consensus: Basic climatological characteristics of the International Cooperative for Aerosol Prediction Multi-Model Ensemble (ICAPMME). Atmospheric Chemistry and Physics, 15(1), 335-362. https://doi.org/10.5194/acp-15-335-2015

Shi, Y. R., Levy, R. C., Eck, T. F., Fisher, B., Mattoo, S., Remer, L. A., et al. (2019). Characterizing the 2015 Indonesia fire event using modified MODIS aerosol retrievals. Atmospheric Chemistry and Physics, 19, 259-274. https://doi.org/10.5194/acp-19-259-2019

Sinyuk, A., Holben, B. N., Smirnov, A., Eck, T. F., Slutsker, I., Schafer, J. S., et al. (2012). Assessment of error in aerosol optical depth measured by AERONET due to aerosol forward scattering. Geophysical Research Letters, 39, L23806. https://doi.org/10.1029/ 2012GL053894

Smirnov, A., Holben, B. N., Dubovik, O., Frouin, R., Eck, T. F., \& Slutsker, I. (2003). Maritime component in aerosol optical models derived from Aerosol Robotic Network data. Journal of Geophysical Research, 108(D1), 4033. https://doi.org/10.1029/2002JD002701

Sumarga, E., Hein, L., Hooijer, A., \& Vernimmen, R. (2016). Hydrological and economic effects of oil palm cultivation in Indonesian peatlands. Ecology and Society, 21(2), 52. https://doi.org/10.5751/ES-08490-210252

Taufik, M., Torfs, P. J. J. F., Uijlenhoet, R., Jones, P. D., Murdiyarso, D., \& Van Lanen, H. A. J. (2017). Amplification of wildfire area burnt by hydrological drought in the humid tropics. Nature Climate Change, 7(6), 428-431. https://doi.org/10.1038/NCLIMATE3280

Torres, B., Dubovik, O., Toledano, C., Berjon, A., Cachorro, V. E., Lapyonok, T., et al. (2014). Sensitivity of aerosol retrieval to geometrical configuration of ground-based sun/sky radiometer observations. Atmospheric Chemistry and Physics, 14(2), 847-875. https://doi.org/ 10.5194/acp-14-847-2014

Turquety, S., Logan, J. A., Jacob, D. J., Hudman, R. C., Leung, F. Y., Heald, C. L., et al. (2007). Inventory of boreal fire emissions for North America in 2004: Importance of peat burning and pyroconvective injection. Journal of Geophysical Research, 112(D12), D12S03. https:// doi.org/10.1029/2006JD007281

Wiggins, E. B., Czimczik, C. I., Santos, G. M., Chen, Y., Xu, X., Holden, S. R., et al. (2018). Smoke radiocarbon measurements from Indonesian fires provide evidence for burning of millennia-aged peat. Proceedings of the National Academy of Sciences, 115(49), 12,419-12,424. https://doi.org/10.1073/pnas.1806003115 